\title{
Genome-based Classification of Streptomyces Pinistramenti sp. nov., a Novel Actinomycete Isolated From a Pine Forest Soil in Poland With a Focus on Its Biotechnological and Ecological Properties
}

\author{
Magdalena Śwecimska \\ Nicolaus Copernicus University \\ Patrycja Golinska ( $\sim$ golinska@umk.pl ) \\ Nicolaus Copernicus University https://orcid.org/0000-0001-9154-8191 \\ Michael Goodfellow \\ Newcastle University
}

\section{Research Article}

Keywords: Streptomyces pinistramenti, Genome, Polyphasic taxonomy, Phylogeny, Biosynthetic Gene Clusters, Antimicrobial activity

Posted Date: January 10th, 2022

DOI: https://doi.org/10.21203/rs.3.rs-1173277/v1

License: (c) (i) This work is licensed under a Creative Commons Attribution 4.0 International License. Read Full License

Version of Record: A version of this preprint was published at Antonie van Leeuwenhoek on April 11th, 2022. See the published version at https://doi.org/10.1007/s10482-022-01734-8. 


\section{Abstract}

A genomic-based polyphasic study was undertaken to establish the taxonomic status and biotechnological and ecological potential of a Streptomyces strain, isolate $\mathrm{SF}^{2} 8^{\top}$, that was recovered from the litter layer in a polish Pinus sylvestris forest. The isolate had morphological characteristics and chemotaxonomic properties consistent with its classification in the genus Streptomyces. It formed long straight chains of spores with smooth surfaces, contained $L L$-diaminopimelic acid and glucose and ribose in whole-organism hydrolysates, produced major proportions of straight, iso- and anteiso- fatty acids, hexa- and octa-hydrogenated menaquinones with nine isoprenoid units and had a polar lipid pattern composed of diphosphatidylglycerol, phosphatidylethanolamine, phosphatidylmethylethanolamine, glycophospholipids and three uncharacterized components. Phylogenetic trees prepared using 16S rRNA gene and multilocus gene sequences of conserved housekeeping genes showed that the isolate formed a branch that was loosely associated with the type strains of several validly published Streptomyces species. A draft genome generated for the isolate was rich in natural product-biosynthetic gene clusters with the potential to produce new specialised metabolites, notably antibiotics, and stress related genes which provide an insight into how they may have adapted to the harsh conditions that prevail in acidic forest soils. A phylogenomic tree based on the genomes of the isolate and its phylogenetic neighbours confirmed that it formed a distinct lineage well separated from its closest evolutionary relatives. The isolate shared low average nucleotide index and digital DNA:DNA hybridization values with its phylogenomic neighbours and was also distinguished from them using a combination of cultural and micromorphological properties. Given this wealth of taxonomic data it is

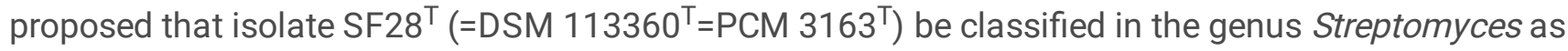
Streptomyces pinistramenti sp. nov. The isolate showed pronounced antimicrobial activity, especially against fungal plant pathogens.

\section{Introduction}

The genus Streptomyces was proposed by Waksman and Henrici (1943) for aerobic, filamentous, spore-forming actinomycetes and its formal description subsequently emended by Kämpfer (2012). The genus currently includes over 800 validly published species (http://www.bacterio.net/streptomyces.html) but remains underspeciated (Hamm et al. 2017; Sivalingam et al. 2019). Multilocus sequence analyses of concatenated, protein coding, conserved house-keeping genes and associated phenotypic properties provide a more reliable way of recognizing novel Streptomyces species than corresponding studies based on 16S rRNA gene sequences (Labeda et al. 2012, 2017; Zhuang et al. 2020). It is also clear that genomic-based classifications are accelerating progress in streptomycete systematics as they provide greater resolution between closely related Streptomyces species than corresponding trees based on single and concatenated sequences of conserved genes (Carro et al. 2018; Nouioui et al. 2018; Kusuma et al. 2021). In addition, improved metrics, such as pairwise average nucleotide index (ANI) and in silico DNA:DNA hybridization (DDH) values, facilitate the recognition of species boundaries (Chun et al. 2018).

Streptomycetes are a unique source of antibiotics which include many used in agriculture, medicine and veterinary practice (Barka et al. 2015; Chater, 2016; Qi et al. 2021). Members of the genus are considered to be gifted (Baltz $2017,2019)$ as they have large genomes ( $\geq 8.0 \mathrm{Mbp}$ ) rich in natural product-biosynthetic gene clusters (NP-BGCs) with the potential to encode for novel and uncharacterized antibiotics of potential therapeutic value, as exemplified by Streptomyces leeuwenhoekii strains isolated from extreme hyper-arid Atacama desert soils (Busarakam et al. 2014; Gomez-Escribano et al. 2015; Castro et al., 2018). Novel streptomycetes from extreme biomes are proving to be a potential rich source of new bioactive molecules (Goodfellow et al. 2018; Rateb et al. 2018; Sivalingam et al. 
2019; Sivakala et al., 2021) thereby underpinning the premise that abiotic conditions in extreme biomes select for strains with the capacity to synthesize novel specialised metabolites (Bull and Stach 2007; Bull 2011; GomezEscribano et al. 2015). However, little attention has been focused on the delineation of Streptomyces species isolated from coniferous forest soils (Golińska et al. 2022), exceptions include the recognition of Streptomyces abietis (Fuijii et al. 2013), Streptomyces pini (Madhaiyan et al. 2016) and Streptomyces piniterrae (Zhuang et al. 2020). Streptomycetes from pine forest soils are also known to be antagonistic towards fungal pathogens of pine seedlings (Golińska and Dahm, 2013). It is becoming increasingly apparent that whole-genomes of actinomycetes isolated from extreme habitats contain the stress-related genes that can provide an insight into how they adapt to harsh abiotic conditions that prevail therein (Busarakam et al. 2016; Abdel-Mageed et al. 2020; Golińska et al. 2022).

The present study, a continuation of earlier work on the diversity of filamentous actinomycetes in coniferous litter and soil (Golińska et al. 2022), was designed to establish the taxonomic provenance of a Streptomyces strain, isolate SF $28^{\top}$, recovered from pine forest litter and to determine its ability to inhibit the growth of fungal pathogens. The isolate and its closest phylogenomic neighbours were the subject of a polyphasic study that included information drawn from whole-genome sequences. The resultant data show that the strain inhibits the growth of diverse fungal phytopathogens and belongs to a new Streptomyces species, designated Streptomyces pinistramenti sp. nov.

\section{Materials And Methods}

\section{Isolation, maintenance and cultural conditions}

Strain SF28 ${ }^{\top}$ was isolated from partially decomposed needles (F-horizon) under Pinus sylvestris trees growing on

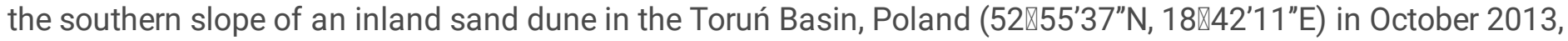
using a standard dilution plating procedure (Goodfellow et al. 1967) and starch-casein agar (Küster and Williams 1964) adjusted to $\mathrm{pH} 4.5$ using $1 \mathrm{M} \mathrm{HCl}$. Details of the sampling site and the selective isolation procedure have been described previously (Golińska et al. 2016). The isolate was maintained on starch-casein agar slopes (pH 5.5) at room temperature and as suspensions of mycelial fragments and spores in $20 \%(\mathrm{v} / \mathrm{v})$ glycerol at $-80^{\circ} \mathrm{C}$. Biomass for most of the chemotaxonomic and molecular systematic studies was prepared by growing the strain in flasks of yeast extract-malt extract broth (ISP2; International Streptomyces Project medium 2; Shirling and Gottlieb 1966), adjusted to $\mathrm{pH} 5.5$, and shaken at $150 \mathrm{rpm}$ for 3 weeks at $28^{\circ} \mathrm{C}$. Cells were harvested by centrifugation and washed three times in sterile distilled water; biomass for the chemotaxonomic analyses was freeze dried and that for the molecular systematic studies stored at $-20^{\circ} \mathrm{C}$.

\section{Phylogenetic analyses}

Genomic DNA was extracted from the isolate using a GenElute ${ }^{\mathrm{TM}}$ Bacterial Genomic Kit (Sigma-Aldrich, Germany) and a 16S rRNA gene amplified by PCR following procedures described by Golińska et al. (2013a,b). The PCR product was purified using a purification kit (Qiagen, Germany), according to manufacturer instructions, and a quality check made using a NanoDrop 2000 spectrophotometer (Thermo Fisher Scientific, USA). The purified PCR product was sequenced at the Institute of Biochemistry and Biophysics (IBB) of the Polish Academy of Sciences in Warsaw, Poland, using an ABI 3730xI Genetic Analyzer (Applied Biosystems, Thermo Fisher Scientific, USA).

The almost complete 16S rRNA gene sequence of the isolate was compared with corresponding sequences of type strains of closely related species using the EzBioCloud server (https://www.ezbiocloud.net; Yoon et al. 2017). 
Maximum-likelihood (ML) and maximum-parsimony (MP) phylogenetic trees were generated using the Single-Gene Trees Phylogeny online tool (https://www.dsmz.de/services/online-tools/single-gene-phylogenies; Meier-Kolthoff et al. 2013a) adapted for single genes. Multiple sequence alignments were generated using MUSCLE software (Edgar 2004) and a ML tree was inferred from alignments with RAxML (Stamatakis 2014) using rapid bootstrapping together with the auto maximal-relative-error (MRE) bootstrapping criterion (Pattengale et al. 2010). Similarly, a MP tree was constructed from alignments with the Tree Analysis New Technology (TNT) program (Goloboff et al. 2008) using 1000 bootstraps together with tree bisection and reconnection branch swapping and ten random sequence replicates. The sequences were checked for compositional bias using the $X^{2}$ test, as implemented in PAUP* (Swofford 2002). The neighbour-joining algorithm (Saitou and Nei 1987) and the MEGA7 software package (Kumar et al. 2016) were used to generate a phylogenetic tree and evolutionary distances were calculated using the Kimura2-parameter model (Kimura 1980) with 1000 bootstrap repetitions (Felsenstein 1985). The root position of the trees were determined using a 16S rRNA gene sequence taken from the genome of Kitasatospora setae DSM $43861^{\top}$ (NC_016109.1) using the SEED viewer (Aziz et al. 2012). A multilocus genome analysis based on 16S rRNA, atpD, $g y r B$, recA and $r p o B$ gene sequences was carried out using an established procedure (Carro et al. 2012) and a MLSA tree generated from nearly $4000 \mathrm{nt}$ using the ML algorithm. Sequence data from all of these genes for each of the tested strains have been deposited in GenBank with the accession numbers shown in Table S1.

\section{Cultural, morphological and phenotypic properties}

The growth and cultural properties of the isolate were recorded from tryptone-yeast extract, yeast extract-malt extract, oatmeal, inorganic salts-starch, glucose-asparagine, peptone-yeast extract-iron and tyrosine agars (ISP media 1-7; Shirling and Gottlieb 1966) and from Bennett's and modified Bennett's agar (Jones 1949), HSA5 agar (Busti et al. 2014), nutrient (Becton Dickinson, USA) and 100-fold diluted nutrient agar (Becton Dickinson, USA) and tap water (Harris 1986) agar after 4 weeks incubation at $28^{\circ} \mathrm{C}$. The colour of aerial and substrate mycelia and diffusible pigments were determined by comparison against NBS/IBCC Colour Charts (Kelly 1958). Hyphal and spore chain features of the isolate were recorded on acidified ISP2 agar plates (pH 5.5), after 4 weeks at $28^{\circ} \mathrm{C}$, using the coverslip technique of Kawato and Shinobu (1959). Spore arrangement and spore surface ornamentation were established by examining gold-coated dehydrated preparations with growth taken from ISP2 agar plates ( $\mathrm{pH} 5.5)$, using the procedure described by O'Donnell et al. (1993) and a scanning electron microscope (Model 1430 V P, LEO Electron Microscopy Ltd, Cambridge, England).

The isolate was also examined for a combination of phenotypic properties. Its ability to grow over a range of $\mathrm{pH}$ values ( $\mathrm{pH} 4-13$ at single unit intervals), temperatures $\left(4,10,15,20,25,30,35,40^{\circ} \mathrm{C}\right)$ and in the presence of various $\mathrm{NaCl}$ concentrations (1-15 at single unit intervals) were determined using acidified ISP2 agar (Shirling and Gottlieb 1966) as the basal medium; the $\mathrm{pH}$ levels were achieved using $\mathrm{KH}_{2} \mathrm{PO}_{4} / \mathrm{HCl}(\mathrm{pH}$ range 4-5), $\mathrm{KH}_{2} \mathrm{PO}_{4} / \mathrm{K}_{2} \mathrm{HPO}_{4}\left(0.1 \mathrm{M}\right.$ both, $\mathrm{pH}$ range 6-8) and $\mathrm{K}_{2} \mathrm{HPO}_{4} / \mathrm{NaOH}$ (pH range 9-13) buffer systems. Standard biochemical, degradative and physiological properties were examined using media and methods described by Williams et al. (1983), albeit with media adjusted to $\mathrm{pH}$ 5.5. All of the tests were carried out, in triplicate, using 12well plates that were inoculated using a standard inoculum corresponding to 5 on the McFarland scale (Murray et al. 1999) and a multipoint inoculator (Mast UrißDot, Mast Group Ltd., Merseyside, UK); the inoculated plates were incubated for 3 weeks at $28^{\circ} \mathrm{C}$ (apart from the temperature tests). The enzymic activities of the isolate were determined, in duplicate, using API-ZYM kits (BioMerieux, France), according to the manufacturer's instructions.

\section{Chemotaxonomy}


Isolate SF $28^{\top}$ was examined for the presence of chemical markers using standard chromatographic methods with appropriate controls. The thin-layer chromatography (TLC) was used to determine isomers of diaminopimelic acid following Staneck and Roberts (1974) and whole-organism sugars according to Hasegawa et al. (1983). Isoprenoid quinones and polar lipids were extracted from freeze-dried cells, as described by Minnikin et al. (1984) and separated using high performed liquid chromatography (HPLC; Kroppenstedt 1985) and two-dimensional TLC (Minnikin et al. 1984), respectively. Cellular fatty acids were extracted, methylated after Miller (1982) with minor modifications from Kuykendall et al. (1988), analysed using the protocol of the Sherlock Microbial Identification (MIDI) system, version 5 (Sasser 1990) and the resultant peaks identified using the ACTIN1 3.80 database.

\section{Whole genome sequencing and phylogenomic analyses}

Genomic DNA was extracted from biomass of isolate SF $28^{\top}$ following growth in ISP2 broth for 7 days at $28^{\circ} \mathrm{C}$ using the protocol provided by MicrobesNG (Birmingham, UK; http://www.microbesng.uk) and sequenced on a MiSeq instrument (Illumina, San Diego, USA). Genomic DNA libraries were prepared at MicrobesNG using Nextera XT library preparation kits. The purity and concentration of the extracted genomic DNA was measured using the Microlab STAR handling system (Hamilton, Birmingham, UK) and libraries generated using Kapa Biosystems library quantification kits designed for Illumina instruments on a LightCycler 96 real time PCR instrument (Roche, West Sussex, UK). The libraries were sequenced following the $2 \times 250$ bp paired-end protocol (MicrobesNG). Reads were trimmed using Trimmomatic software version 0.30 (Bolger et al. 2014) and their quality assessed using in-house scripts from MicrobesNG; those under $1000 \mathrm{bp}$ were discarded. The esultant reads were assembled into contigs using Spades 3.7 software (Bankevich et al. 2012), annotated using Prokka 1.11 (Seemann 2014) and analysed using the SEED Viewer (Aziz et al. 2012). The genome sequence of isolate SF28 ${ }^{\top}$ was deposited in the GenBank database under accession number JAJCXB000000000.

The genome sequences of isolate SF28 ${ }^{\top}$, the type strains of closely related Streptomyces species and Kitasatospora setae DSM $43861^{\top}$ were uploaded onto the Type (Strain) Genome Server (TYGS; Meier-Kolthoff and Göker 2019) and compared using the MASH algorithm which allows a fast approximation of intergenomic relatedness between strains (Ondov et al. 2016). A phylogenomic tree was inferred with FastME 2.1.4 (Lefort et al. 2015) from GBDP distances calculated from the genome sequences and branch lengths scaled using the GBDP distance formula $d_{5}$ (Meier-Kolthoff et al. 2013a); GBDP pseudo-bootstrap support values above branches on the tree were based on 100 replications. The tree was rooted at the midpoint (Farris 1972). Average nucleotide identity (ANI; Rodriguez and Konstantinidis 2016) and digital DNA:DNA hybridization (dDDH; Meier-Kolthoff et al. 2013b) values between genomes of the isolate and its closest phylogenomic neighbours were determined using the online resource from the Rodriguez and Konstantinidis group (http://enve-omics.gatach.edu/) and the GGDC web server (http://ggdc.dsmz.de/ggdc), respectively.

\section{Genome analyses}

The presence of BGCs in the genomes of the isolate and its phylogenomic neighbours was investigated using antiSMASH 6.0 software with "strict" detection criteria and extra features, including KnownClusterBlast, ClusterBlast, SubClusterBlast, MIBiG cluster comparison, ActiveSiteFinder, RREFinder, Cluster Pfam analyses, Pfam-based GO term annotation and TIGRFam analysis (Blin et al. 2021). The distribution of functional gene classes and the presence of stress response genes potentially involved in adaptation to harsh environmental conditions in the genome of isolate SF $28^{\top}$ were analyzed using the RAST-SEED webserver at https://rast.nmpdr.org/

\section{Antimicrobial screens}


The isolate was tested for its ability to inhibit the growth of Bacillus subtilis PCM 2021, Escherichia coli ATCC 25922, Klebsiella pneumoniae ATCC 700603, Micrococcus luteus ATCC 10240, Pseudomonas aeruginosa ATCC 10145 and Staphylococcus aureus ATCC 25923 using a standard agar plug assay (Fiedler 2004). It was grown on ISP2 agar (Shirling and Gottlieb 1966) for 3 weeks at $28^{\circ} \mathrm{C}$ when agar plugs $(\varnothing=5 \mathrm{~mm})$ were taken from the plates and placed in square Petri dishes (Sterilin, UK). Overnight cultures of the reference strains $(50 \mu \mathrm{L})$ grown at $37^{\circ} \mathrm{C}$ were used to seed $25 \mathrm{~mL}$ of Luria Bertani broth (LB, Becton Dickinson, USA) to an optical density (OD) of 0.6 prior to diluting them to an OD of 0.0125 with $100 \mathrm{~mL}$ of LB broth and the same volume of nutrient agar (Becton Dickinson, USA). The resultant preparations were thoroughly mixed and poured into the square Petri dishes containing the plugs and incubated for $24 \mathrm{~h}$ at $37^{\circ} \mathrm{C}$; inhibition zones around the agar plugs were recorded in millimetres. All of the tests were carried out in triplicate.

A co-culture method described by Świecimska et al. (2021) was used to determine the ability of the isolate to inhibit the growth of fungal and fungal-like plant and human pathogens. Briefly, the isolate was streaked as a line across one side of Potato Dextrose Agar (PDA, Becton Dickinson, USA) plates which were incubated for 14 days at $28^{\circ} \mathrm{C}$. The discs $(\varnothing=8 \mathrm{~mm}$ ) of pathogens grown on PDA in Petri plates for 7-14 days were placed on the opposite side of the plates inoculated with the isolate and the preparations incubated for 7 days in the case of Alternaria alternata IOR 1783, Fusarium culmorum and Fusarium oxysporum (isolated from pine roots), Fusarium culmorum D and Fusarium graminearum D (both isolated from wheat), Phytophthora plurivora (isolated from the rhizosphere of oak), Rhizoctonia solani (isolated from pine roots) and Sclerotina sclerotiorum IOR 2242, for 14 days for Fusarium poae A and Fusarium tricinctum A (isolated from wheat), Botritis cinerea IOR 1873, Colletotrichum acutatum IOR 2153, Fusarium culmorum IOR 2333, Fusarium oxysporum IOR 342, Phytophtora cactorum IOR 1925, and for 21 days for Fusarium graminearum A and Fusarium oxysporum D (isolated from wheat), Fusarium solani IOR 825, Phytophthora cryptogea IOR 2080, Phytophthora megasperma IOR 404 and Phoma lingam IOR 2284. The human pathogens, Trichophyton erinacei DSM $25374^{\top}$ and Trichophyton thuringense DSM $25373^{\top}$ were incubated for 14 days. All tests were carried out in triplicate at $28^{\circ} \mathrm{C}$; the positive controls were cultures of the pathogens grown under the same incubation conditions. Inhibition (I) of pathogen growth was calculated using the formula: I (\%) = (C$T / C) \times 100$, where $C$ is the diameter of pathogen growth in the control sample and $T$ the diameter of the pathogen growth in each of the co-culture samples.

\section{Results And Discussion}

Isolate SF28 ${ }^{\top}$ showed chemotaxonomic, cultural and morphological properties consistent with its classification in the genus Streptomyces (Kämpfer 2012; Nouioui et al. 2018). The organism was found to be aerobic, Gram-stain positive, formed an extensively branched substrate mycelium and aerial hyphae that differentiated into long chains of smooth surfaced spores (Fig. 1), grew from pH 4 to 12, from 4 to $30{ }^{\circ} \mathrm{C}$ and in the presence of up to $11 \%, \mathrm{w} / \mathrm{v}$ $\mathrm{NaCl}$. Whole-organism hydrolysates of the isolate contained $L L-\mathrm{A} 2 \mathrm{pm}$, glucose and ribose, the predominant isoprenologues were hexa- and octa-hydrogenated menaquinones with nine isoprene units (74.1 and $23.1 \%$, respectively) and the polar lipid pattern consisted of diphosphatidylglycerol, glycophospholipids, phosphatidylethanolamine (diagnostic component), phosphatidylglycerol, phosphatidylmethylethanolamine, phosphatidylinositol, and 3 unknown lipids, as shown in Figure S1. The fatty acid profile contained major proportions of anteiso- $\mathrm{C}_{15: 0}(26.2 \%), \mathrm{C}_{16: 0}(20.0 \%)$, iso- $\mathrm{C}_{16: 0}(11.0 \%)$ and anteiso- $\mathrm{C}_{17: 0}(11.5 \%)$, smaller proportions $(>11 \%)$ of $\mathrm{C}_{14: 0}(1.4 \%), \mathrm{C}_{15: 0}(2.4 \%), 9$ methyl- $\mathrm{C}_{16: 0}(1.0 \%), \mathrm{C}_{15: 0}$ cis $9(5.3 \%)$, anteiso- $\mathrm{C}_{15: 0} 2 \mathrm{OH}(3.0 \%)$, anteiso- $\mathrm{C}_{17: 1}$ $\mathrm{c}(1.6 \%)$, iso- $\mathrm{C}_{14: 0}(1.7 \%)$, iso- $\mathrm{C}_{15: 0}(8.1 \%)$ and iso- $\mathrm{C}_{17: 0}(3.1 \%)$, and traces of cyclo $\mathrm{C}_{17: 0}$ and iso- $\mathrm{C}_{16: 1} \mathrm{H}$. 
The isolate grew well on ISP2, ISP6, Bennett's and modified Bennett's agar, moderately well on ISP1 and 3 and nutrient agar but poorly or not at all on the remaining media, as shown in Table S2.

\section{Phylogeny}

The almost complete 16S rRNA gene sequence generated for isolate SF28 ${ }^{\top}$ (1414 [nt]) was deposited in Genbank (accession number: OK576049). The isolate forms a branch in a well-supported subclade in the ML/MP trees which includes the type strains of 22 Streptomyces species few of which are closely related based on low bootstrap values. Isolate SF28 ${ }^{\top}$ is most closely related to the type strains of Streptomyces kronopolitis (Liu et al. 2016), Streptomyces chattanoogensis (Burns and Holtman 1959) and Streptomyces lydicus (De Boer et al. 1956), showing 16S rRNA gene sequence similarities with them of 99.3\% (10 nt differences), 99.2\% (12 nt differences) and 99.2\% (12 nt differences), respectively (Fig. S2). The corresponding sequences between the isolate and the type strains of the remaining Streptomyces species ranged from 98.0 (28 nt differences) to 98.9\% (15 nt differences; Table S3). The isolate and the $S$. kronopolitis strain formed a well-supported branch in the neighbour-joining tree that was loosely associated with the other Streptomyces strains (Fig. S3).

Multilocus sequence analyses of single copies of conserved housekeeping genes provide greater resolution between closely related streptomycetes than corresponding 16S rRNA gene sequence studies as they are based on comparisons of many more nucleotide sequences (Labeda et al. 2012, 2017; van der Aart et al. 2019). In the present study, the isolate was assigned to a subcluster that was supported by a $64 \%$ bootstrap value (Fig. 2). This taxon encompassed the type strains of 10 Streptomyces species, eight of which featured in the subclade defined in the $16 \mathrm{~S}$ rRNA gene tree. Isolate $\mathrm{SF} 28^{\mathrm{T}}$ was most closely related to the type strains of $S$. chattanoogensis, Streptomyces inhibens (Jin et al. 2019), S. kronopolitis and S. lydicus sharing nucleotide sequence similarities with them of $96.2 \%, 96.0 \%, 95.9 \%$ and $95.8 \%$ (Table S4). The MLSA evolutionary distances between the isolate and the type strains of the most closely related Streptomyces species ranged from 0.039 to 0.124 (Table S5), values well above the species threshold of 0.007 used to distinguish between closely related strains, including streptomycetes (Rong and Huang 2012, 2014). Based on these data isolate SF28 ${ }^{\top}$ is not closely related to the S. chattanoogensis, S. inhibens and $S$. kronopolitis strains as it shows evolutionary distance values with them of $0.039,0.040$ and 0.042 , respectively. A corresponding distance score of 0.43 was recorded between the isolate and the type strains of Streptomyces celluloflavus (Nishimura et al 1953; Madhaiyan et al. 2020), and S. lyidicus.

Greater confidence can be placed on the topology of phylogenomic trees than in corresponding 16S rRNA and MLSA trees as they are based on millions not thousands of unit characters (Nouioui et al. 2018). It is evident from the phylogenomic tree (Fig. 3 ) that the sequence generated for isolate SF $28^{\top}$ and corresponding data available on the type strains of its phylogenetic relatives show that the isolate forms a singleton in a well-supported subclade which includes the type strains of 14 Streptomyces species, including those representing $S$. chattanoogensis, S. kronopolitis and S. lyidicus.

\section{Comparison of genomes}

The draft genome sequence of isolate SF28 ${ }^{\top}$ has been deposited in GenBank (accession number JAJCXB000000000). It is composed of 133 contigs, has 6594 protein coding genes, 74 RNA genes and L50 and N50 scores of 21 and 117612, respectively. The total genome size is $7.85 \mathrm{Mbp}$ and the digital (d) G+C content $71.5 \%$. The major classes of functional gene clusters in the genome of the isolate are associated with amino acids and derivatives (441), carbohydrates (297) and protein (237) metabolism, as shown in Figure S4. In general, the 
genome of the isolate is of a similar size to those of its evolutionary neighbours, as exemplified by $S$. chattanoogensis NRRL ISP-5002 ${ }^{\top}$ (9.1 Mbp; Burns and Holtman 1959), S. celluloflavus NRRL B-2493 ${ }^{\top}$ (8.65 Mbp; Madhaiyan et al. 2020), Streptomyces decoyicus NRRL $2666^{\top}$ (8.6 Mbp; Kumar and Goodfellow 2010), S. inhibens NEAU-D10 ${ }^{\top}$ (9.5 Mbp; Jin et al. 2019), S. kronopolitis NEAU-ML8 ${ }^{\top}$ (7.8 Mbp; Liu et al. 2016), S. Iydicus ATCC $25470^{\top}$ (7.9 Mbp; De Boer et al. 1956) and S. piniterraejys $28^{\top}$ (8.5 Mbp; Zhuang et al. 2020).

The $\mathrm{dDDH}$ relatedness values between the isolate and its evolutionary relatives falls within the range 21.7 to $28.7 \%$ (Table S6), which is well below the $70 \%$ the threshold for the assignment of bacterial strains to the same species (Wayne et al. 1987). This Table shows that the corresponding ANI similarities range from 80.5 to $85.1 \%$, similarities below the recommended threshold (95-96\%) for species delineation (Richter and Rosselló-Móra 2009; Lee et al. 2016). These results indicate that isolate SF $28^{\top}$ represents a new Streptomyces species that is only loosely associated with its evolutionary relatives. It seems likely that the position of the isolate and its closest phylogenetic/phylogenenomic relatives will only be settled by the addition of new species to this unstable part of Streptomyces gene trees. Other Streptomyces species found to form distinct lineages in Streptomyces gene trees include Streptomyces adelaidensis (Kaewkla et al. 2021), Streptomyces leeuwenhoekii (Busarakam et al. 2014) and Streptomyces tardus (Králová et al. 2021).

\section{Phenotypic properties}

Closely related species can usually be distinguished using a broad-range of phenotypic properties (Komaki and Tamura, 2019; Kusuma et al. 2021). Cultural and morphological properties have been shown to be particularly predictive in this respect, as exemplified in extensive phylogenetic analyses of Streptomyces species (Labeda et al. 2012 , 2017). In the present study, isolate SF $28^{\top}$ was examined for cultural and key morphological features, and for its ability to metabolize a broad range of carbon and nitrogen sources, enzymes and growth characteristics. It is particularly encouraging that identical results were recorded for the triplicated cultures, as shown in Table 1 and the species description. Comparison of some of these properties with corresponding data acquired for $S$. decoyicus NRRL $2666^{\top}$, its closest phylogenomic neighbour based on $\mathrm{dDDH}$ similarity, can be distinguished readily using cultural and morphological properties, as well as by associated phenotypic properties that were also recorded using media and methods described by Williams et al. (1983). It is significant that these strains show different properties when grown on oatmeal agar and exhibit markedly different spore chain morphologies (Table 2). In addition, only the isolate grows at $10^{\circ} \mathrm{C}$ and at $\mathrm{pH} 4.0$, and 5.0; it also shows more activity than $S$. decoyicus NRRL $2666^{\top}$ when grown on sole carbon sources. 
Table 1

Phenotypic features which separate isolate $\mathrm{SF}_{28}{ }^{\top}$ from the type strain of $S$. decoyicus

\begin{tabular}{|c|c|c|}
\hline & $\begin{array}{l}\text { Isolate } \\
\text { SF28 }\end{array}$ & $\begin{array}{l}\text { S. decoyicus* } \\
\text { NRRL } 2666^{\top}\end{array}$ \\
\hline \multicolumn{3}{|l|}{ Pigments formed on oatmeal agar. } \\
\hline Aerial spore mass & Bluish grey & $\begin{array}{l}\text { Grey, becoming black } \\
\text { and moist }\end{array}$ \\
\hline Substrate mycelium & $\begin{array}{l}\text { Brownish } \\
\text { grey }\end{array}$ & Deep yellow \\
\hline Diffusible pigment & $\begin{array}{l}\text { Greyish } \\
\text { yellow }\end{array}$ & None \\
\hline \multicolumn{3}{|l|}{ Morphology: } \\
\hline Spore chains & Rectiflexibles & Spiral \\
\hline \multicolumn{3}{|l|}{ Degradation of: } \\
\hline Xylan, xanthine & + & - \\
\hline \multicolumn{3}{|l|}{ Growth on sole carbon sources ( $1 \% \mathrm{w} / \mathrm{v})$ : } \\
\hline $\begin{array}{l}\text { Adonitol, amygdalin, meso-erythritol, inulin, a-lactose, D-raffınose, L- } \\
\text { rhamnose, D-salicin }\end{array}$ & + & - \\
\hline D-Xylose & - & + \\
\hline \multicolumn{3}{|l|}{ Tolerance tests } \\
\hline \multicolumn{3}{|l|}{ Growth tests: } \\
\hline $\mathrm{pH} 4$ and 5 & + & - \\
\hline $10^{\circ} \mathrm{C}$ & + & - \\
\hline \multicolumn{3}{|l|}{ Growth on presence of: } \\
\hline $\mathrm{NaCl} 13 \% \mathrm{w} / \mathrm{v}$ & - & + \\
\hline DNA G+C content (\%) & 71.5 & 70.9 \\
\hline Genome size (Mbp) & 7.85 & 8.63 \\
\hline \multicolumn{3}{|c|}{$\begin{array}{l}\text { *Properties of } S \text {. decoyicus strain are from Kumar and Goodfellow (2010). DNA G+C content and genome size } \\
\text { are from GenBank. Both strains formed spores with smooth surfaces, degraded adenine, gelatin, casein, } \\
\text { hypoxanthine, L-tyrosine and uric acid, used D-arabitol, D-cellobiose, dextrin, D-fructose, D-galactose, glycogen, } \\
\text { D-glucose, glycerol, myo-inositol, D-maltose, D-melezitose, D-ribose, sucrose and D-trehalose as a sole carbon } \\
\text { sources, and L-alanine, L-glutamic acid, L-histidine, L-isoleucine, DL-methionine, L-phenylalanine, L-threonine } \\
\text { and L-valine as sole nitrogen sources, and grew at } \mathrm{pH} 9 \text { and } 10 \text { and } 30^{\circ} \mathrm{C} \text {. None of tested strains hydrolysed } \\
\text { allantoin, degraded starch or used L-arabinose as a sole carbon source. }\end{array}$} \\
\hline
\end{tabular}


Table 2

Antimicrobial activity of isolate $\mathrm{SF}^{2} 8^{\top}$ against fungal and fungal-like organisms evaluated using the co-cultured method.

\begin{tabular}{|c|c|}
\hline Fungi and fungi-like organisms & I [\%] \\
\hline \multicolumn{2}{|l|}{ Plant pathogens } \\
\hline Alternaria alternata IOR 1783 & $85.6 \pm 2.1$ \\
\hline Botritis cinerea IOR 1873 & $82.4 \pm 1.4$ \\
\hline Chalara fraxinea & $61.8 \pm 0$ \\
\hline Fusarium culmorum & $91.9 \pm 2.1$ \\
\hline Fusarium culmorum D & $91.0 \pm 0.6$ \\
\hline Fusarium graminearum A & $91.3 \pm 2.3$ \\
\hline Fusarium graminearum D & $92.5 \pm 2.0$ \\
\hline Fusarium oxysporum IOR 342 & $80.3 \pm 0$ \\
\hline Fusarium poae $\mathrm{A}$ & $58.1 \pm 2.1$ \\
\hline Fusarium solani IOR 825 & $88.9 \pm 1.4$ \\
\hline Fusarium tricinctum A & $50.2 \pm 2.1$ \\
\hline Phoma lingam IOR 2284 & $89.7 \pm 0$ \\
\hline Phytophthora cactorum IOR 1925 & $90.5 \pm 0$ \\
\hline Phytophthora cryptogea IOR 2080 & $60.2 \pm 0.7$ \\
\hline Phytophthora megasperma IOR 404 & $52.1 \pm 2.8$ \\
\hline Phytophthora plurivora & $92.2 \pm 0$ \\
\hline Rhizoctonia solani & $94.4 \pm 0.6$ \\
\hline Sclerotina sclerotiorum IOR 2242 & $89.3 \pm 0.7$ \\
\hline \multicolumn{2}{|l|}{ Human pathogens } \\
\hline Trichophyton erinacei DSM 25374 & $92.0 \pm 0$ \\
\hline T. thuringense DSM 25373 & $78.7 \pm 2.3$ \\
\hline l; \% inhibition of fungal growth. & \\
\hline
\end{tabular}

The isolate can be distinguished from the type strains of Streptomyces species listed in Table S6 as they show different cultural features on oatmeal agar and form spiral chains of spores, albeit ones with smooth surfaces (Kämpfer, 2012; Liu et al. 2016; Kamaki and Tamura 2019; Madhaiyan et al. 2020). It can also be separated from the $S$. chattanoogensis, S. hygroscopicus subsp. glebosus, S. inhibens and S. piniterrae strains as they form spiny, rudged or wrinkled spores in spiral chains (Kämpfer 2012; Jin et al. 2019; Zhuang et al. 2020). 


\section{Antimicrobial activity}

Isolate SF28 ${ }^{\top}$ formed zones of inhibition against the $B$. subtilis $(9.7 \pm 1.2 \mathrm{~mm})$, E.coli $(3.0 \pm 1.0 \mathrm{~mm}), K$. pneumoniae $(2.0 \pm 0.0 \mathrm{~mm})$, M. Iuteus $(8.0 \pm 0.1 \mathrm{~mm}), P$. aeruginosa $(3.0 \pm 0.1 \mathrm{~mm})$ and $S$. aureus $(6.2 \pm 0.6 \mathrm{~mm})$ in the agar plug assays. Similar results have been recorded by members of novel Streptomyces species isolated from natural habitats, including extreme hyper-arid Atacama Desert soils (Sharma et al. 2014; Goodfellow et al. 2017; Abdelkader et al. 2018; Le Roes-Hill et al. 2018). Similarly, the isolate inhibited the growth of diverse fungal pathogens, including representatives of several Fusarium and Phythophthora species, as shown in Table 2. These results provide further evidence that novel Streptomyces species from different habitats, notably from plant rhizospheres and living plant tissues, produce new natural products, especially antifungal antibiotics which inhibit the growth of phytopathogens (Zhao et al. 2017; Singh and Dubey 2018; Qi et al. 2019; Peng et al. 2020) and which thereby show promise as biocontrol agents (Cao et al .2020). It is also interesting that the isolate showed pronounced activity against representatives of the two Trichophyton species (Table 2).

\section{Genome mining}

AntiSMASH predicts BGCs and potential products based on the percentage of genes from the closest known bioclusters showing significant BLAST hits against corresponding clusters in the genomes of strains under consideration (Blin et al. 2021). The genome of isolate SF28 ${ }^{\top}$ was found to contain 29 BGCs, notably ones predicted to encode for druggable molecules such as non-ribosomal peptide synthetases (Table 3). Eleven of the bioclusters showed at least $50 \%$ gene identity with known compounds, as exemplified by those associated with the synthesis of anantin C (75\% gene identity), a peptide antagonist of the atrial natriuretic factor(Tietz et al. 2017), desferrioxamine $\mathrm{E}$ (100\% gene identity), a siderophore which forms stable hexadentate complexes with ferric ions (Barona-Gómez et al. 2004), ectoine (100\% gene identity), which protects against osmotic stress and desiccation (Prabhu et al. 2004), ethylenediaminesuccinic acid hydroxyarginine (EDHA) (100\% gene identity), a second line siderophore (Spohn et al. 2018), and lugdunomycin (74\% gene identity), a novel aromatic polyketide (Wu et al. 2019). Similarly, several bioclusters are predicted to encode for a range of products, as exemplified by those involved in the synthesis of alkylresorcinol (100\% gene identity) which has multiple biological functions (Funabashi et al. 2008; Nakano et al. 2012), a heat-stable antifungal factor (75\% gene identity) that inhibits the growth of diverse fungi (Yu et al. 2007) and the tallysomycins (TLMs) (60\% gene identity), antitumor antibiotics (Tao et al. 2007). 
Table 3

The distribution of BGCs in the genome of isolate SF28 ${ }^{\top}$

\begin{tabular}{|c|c|c|c|c|c|}
\hline Gene type & Product & $\begin{array}{l}\text { Span } \\
\text { (nt) }\end{array}$ & $\begin{array}{l}\text { Gene } \\
\text { similarity } \\
(\%)\end{array}$ & $\begin{array}{l}\text { Most similar } \\
\text { biosynthetic gene } \\
\text { cluster }\end{array}$ & $\begin{array}{l}\text { Similarity } \\
(\%)\end{array}$ \\
\hline Ectoine & Ectoine & $\begin{array}{l}123,024- \\
133,437\end{array}$ & 100 & $\begin{array}{l}\text { Streptomyces } \\
\text { kasugaensis } \\
\text { BCRC } 12349\end{array}$ & 100 \\
\hline \multirow[t]{4}{*}{ Lassopeptide } & \multirow[t]{4}{*}{ Anantin C } & \multirow[t]{4}{*}{$1-14,4$} & \multirow[t]{4}{*}{75} & $\begin{array}{l}\text { Geodermatophilus } \\
\text { siccatus DSM } \\
45419\end{array}$ & 25 \\
\hline & & & & $\begin{array}{l}\text { Streptomyces } \\
\text { cyaneogriseus } \\
\text { subsp. } \\
\text { noncyanogenus }\end{array}$ & 25 \\
\hline & & & & $\begin{array}{l}\text { Streptomyces } \\
\text { leeuwenhoekii }\end{array}$ & 25 \\
\hline & & & & $\begin{array}{l}\text { Streptomyces } \\
\text { kasugaensis } \\
\text { BCRC } 12349\end{array}$ & 25 \\
\hline NAPAA & $\begin{array}{l}\text { Eethylenediaminesuccinic } \\
\text { acid hydroxyarginine } \\
(E D H A)\end{array}$ & $1-38,693$ & 100 & $\begin{array}{l}\text { Kitasatospora sp. } \\
\text { CB02891 }\end{array}$ & 37 \\
\hline $\begin{array}{l}\text { NRPS/ Type } 1 \text { PKS } \\
\text { (T1PKS) }\end{array}$ & Tallysomycin A & $\begin{array}{l}9,621- \\
84,434\end{array}$ & 60 & $\begin{array}{l}\text { Actinosynnema } \\
\text { mirum DSM } \\
43827\end{array}$ & 39 \\
\hline \multirow[t]{2}{*}{$\begin{array}{l}\text { NRPS/ Type } 1 \text { PKS } \\
\text { (T1PKS) }\end{array}$} & \multirow[t]{2}{*}{$\begin{array}{l}\text { Heat-stable antifungal } \\
\text { factor }\end{array}$} & \multirow[t]{2}{*}{$\begin{array}{l}130,781- \\
204,146\end{array}$} & \multirow[t]{2}{*}{75} & $\begin{array}{l}\text { Streptomyces sp. } \\
\text { CS090A }\end{array}$ & 30 \\
\hline & & & & $\begin{array}{l}\text { Streptomyces } \\
\text { fulvissimus DSM } \\
40593\end{array}$ & 30 \\
\hline \multirow[t]{7}{*}{ Siderophore } & \multirow[t]{7}{*}{ Desferrioxamine E } & $\begin{array}{l}71,733- \\
81,169\end{array}$ & 100 & $\begin{array}{l}\text { Streptomyces sp. } \\
\text { MOE7 }\end{array}$ & 83 \\
\hline & & & & $\begin{array}{l}\text { Streptomyces } \\
\text { lydicus GS93 }\end{array}$ & 83 \\
\hline & & & & $\begin{array}{l}\text { Streptomyces } \\
\text { lydicus } 103\end{array}$ & 83 \\
\hline & & & & $\begin{array}{l}\text { Streptomyces } \\
\text { lydicus WYEC } 108\end{array}$ & 83 \\
\hline & & & & $\begin{array}{l}\text { Streptomyces sp. } \\
\text { RPA4-5 }\end{array}$ & 83 \\
\hline & & & & $\begin{array}{l}\text { Streptomyces } \\
\text { platensis ATCC } \\
23948\end{array}$ & 83 \\
\hline & & & & $\begin{array}{l}\text { Streptomyces sp. } \\
\text { NEAU-S7GS2 }\end{array}$ & 83 \\
\hline
\end{tabular}




\begin{tabular}{|c|c|c|c|c|c|}
\hline Gene type & Product & $\begin{array}{l}\text { Span } \\
(\mathrm{nt})\end{array}$ & $\begin{array}{l}\text { Gene } \\
\text { similarity } \\
(\%)\end{array}$ & $\begin{array}{l}\text { Most similar } \\
\text { biosynthetic gene } \\
\text { cluster }\end{array}$ & $\begin{array}{l}\text { Similarity } \\
(\%)\end{array}$ \\
\hline & & & & $\begin{array}{l}\text { Streptomyces } \\
\text { lydicus strain A02 }\end{array}$ & 83 \\
\hline & & & & $\begin{array}{l}\text { Streptomyces sp. } \\
\text { GS7 }\end{array}$ & 83 \\
\hline & & & & $\begin{array}{l}\text { Streptomyces sp. } \\
2323.1\end{array}$ & 83 \\
\hline Type 2 PKS (T2PKS) & Lugdunomycin & $\begin{array}{l}37,499- \\
80,898\end{array}$ & 74 & $\begin{array}{l}\text { Streptomyces sp. } \\
\text { CB02414 }\end{array}$ & 36 \\
\hline \multirow[t]{4}{*}{ Type 2 PKS (T2PKS) } & Spore pigment & $\begin{array}{l}84,575- \\
157,09\end{array}$ & 83 & $\begin{array}{l}\text { Streptomyces sp. } \\
\text { PAMC } 26508\end{array}$ & 23 \\
\hline & & & & $\begin{array}{l}\text { Streptomyces } \\
\text { microflavus CG } \\
893\end{array}$ & 23 \\
\hline & & & & $\begin{array}{l}\text { Streptomyces } \\
\text { pratensis ATCC } \\
33331\end{array}$ & 23 \\
\hline & & & & $\begin{array}{l}\text { Streptomyces sp. } \\
\text { Root1304 }\end{array}$ & 23 \\
\hline Type 3 PKS (T3PKS) & Naringenin & $\begin{array}{l}213,991- \\
241,849\end{array}$ & 100 & $\begin{array}{l}\text { Streptomyces } \\
\text { griseorubens JSD- }\end{array}$ & 26 \\
\hline $\begin{array}{l}\text { Type } 3 \text { PKS (T3PKS)/ } \\
\text { Terpene }\end{array}$ & Alkylresorcinol & $\begin{array}{l}59,464- \\
105,812\end{array}$ & 100 & $\begin{array}{l}\text { Nonomuraea sp. } \\
\text { WYY166 }\end{array}$ & 22 \\
\hline $\begin{array}{l}\text { Terpene/Lanthipeptide } \\
\text { class I/NRPS }\end{array}$ & Hopene & $\begin{array}{l}221,191- \\
291,727\end{array}$ & 69 & $\begin{array}{l}\text { Streptomyces } \\
\text { platensis ATCC } \\
23948\end{array}$ & 100 \\
\hline
\end{tabular}

The SEED analyzes (Aziz et al. 2012) show that genome of isolate SF28 ${ }^{\top}$ contains 61 putative stress related genes, notably those linked to cold and heat shock responses, DNA repair and oxidative stress (Table S7, Fig. S4). This complement of genes included $c s p C$ and $c s p E$ which express for cold shock proteins (Etchegaray and Inouye 1999) and chaperone genes such as $c / p B, c / p C, c / p X$ and $h r c A$ which are involved in responses to heat shock (Li et al. 2011). In turn, genes such as betA, bet $B$ and $p r o U$ are involved in the uptake of betaine and choline, metabolites, which help in responses to osmotic stress (Boncompagni et al. 1999; Nau-Wagner et al. 2012), as do enzymes expressed by genes katE and soxR (Normand et al. 2012; Golińska et al. 2020), and the products of genes trx and $\operatorname{tr} x R$ (Kim et al. 2008). The genome of the isolate also included genes such as $R e c F, R e c O$ and $R e c R, U v r D$ which are associated with DNA repair and stabilizing (Hickson 2003; Kang and Blaser 2006). The detection of CoxG gene which encodes for a subunit of carbon monoxide dehydrogenase suggest that the isolate may be able to adapt to chemolitotrophic lifestyle by using carbon monoxide as a carbon and energy source (Lorite et al. 2000), as is the case with the type strains of Streptomyces thermocarboxydovorans and Streptomyces thermocarboxydus (Kim et al. 1998). The genome of the isolate is also rich in genes that express for DNA polymerase Sigma factors, as shown in Table S7. Some of these genes, such as sigB, which is involved in osmotic stress, is upregulated under 
acidic conditions (Kim et al. 2008). These authors also showed that this phenomenon applied to heat shock genes, including ones found in the genome of the isolate, notably ones supressing for proteins belonging to the DnaK family and chaperones, such as GroEL2. It is also interesting that the genome of the isolate contained gene atpA, which is involved in a transmembrane protein transport system, is known to enhance survival of bacteria under acidic conditions (Guan and Liu 2020). These results provide further evidence that $\mathrm{pH}$ is a major factor governing the survival and distribution of streptomycetes in acidic soils (Williams et al. 1971; Goodfellow and Williams 1983).

\section{Conclusions}

The isolate showed antimicrobial activity, notably against fungal pathogens, had a large genome rich in BGCs predicted to encode for a broad range of specialised metabolites, especially putatively new antibiotics and stress related genes, notably ones associated with adaptation to acidic conditions. It is also evident from the sequence data that isolate SF $28^{\top}$ forms a distinct lineage within the evolutionary variation occupied by Streptomyces species. It is loosely associated with its closest phylogenetic/phylogenomic neighbours, a point underlined by corresponding low ANI and dDDH similarities. It can also be distinguished from these organisms using key cultural and micromorphological properties. Consequently, the isolate is considered to represents a novel Streptomyces species for which the name Streptomyces pinistramenti sp. nov. is proposed.

\section{Description of Streptomyces pinistramenti sp. nov.}

Streptomyces pinistramenti (pi.ni.stra.men'ti. L. fem. n. pinus, pine tree; L. neut. n. stramentum, litter; N.L. gen. n. pinistramenti, of pine litter)

Aerobic, Gram stain-positive actinomycete which forms an extensively branched substrate mycelium and aerial hyphae that differentiate into long chains of smooth surfaced spores. Grows from 4 to $30^{\circ} \mathrm{C}$, optimally around $25^{\circ} \mathrm{C}$, from $\mathrm{pH} 4-12$, abundantly from $\mathrm{pH} 5-11$, and in the presence of $0-11 \% \mathrm{NaCl} \mathrm{w} / \mathrm{v}$, optimally without $\mathrm{NaCl}$. Grows well on yeast extract-malt extract agar forming a brownish grey substrate mycelium, a greenish grey aerial mycelium and a greyish yellow diffusible pigment. Hydrolyses aesculin and arbutin, but not allantoin or urea. Nitrate is reduced. Adenine, casein, gelatin, hypoxanthine, Tweens 40 and 60, L-tyrosine, uric acid, xanthine and xylan are degraded, but not chitin, elastin, guanine, starch, Tweens 20 or 80 . Positive for cystine, leucine and valine arylamidases, $a$ - chymotrypsin, acid- and alkaline- phosphatases, a-galactosidase, $\beta$-glucosidase, a-mannosidase, naphthol-AS-BI-phosphohydrolase and trypsin, but negative for esterase (C4), esterase lipase (C8), $a$-fucosidase, $\beta$ galactosidase, N-acetyl- $\beta$-glucosaminidase a-glucosidase, $\beta$-glucuronidase and lipase (C14) (API-ZYM tests). Adonitol, amygdalin, D-arabitol, D-cellobiose, dextrin, meso-erythritol, D-fructose, D-galactose, D-glucosamine, D-

glucose, glycerol, glycogen, meso-inositol, inulin, D-lactose, D-maltose, D-mannitol, D-melezitose, D-melibiose, a- and $\beta$-methyl-D-glucosides, D-raffinose, L-rhamnose, D-ribose, D-salicin, D-sucrose, D-trehalose and xylitol are metabolized as a sole carbon sources, but not L-arabinose, L-arabitol, D-glucuronic acid or D-xylose (all at 1\% w/v). Metabolizes acetate, citrate, fumarate, hippurate, propionate, pyruvate and succinate, but not adipate, benzoate, butyrate or oxalate (sodium salts) or para-hydroxybenzoic acid (all at $0.1 \% \mathrm{~W} / \mathrm{v}$ ). L-alanine, L-arginine, L-asparagine, L-cysteine, ethanolamine, L-glutamic acid, L-histidine, L-hydroxyproline, L-isoleucine, L-methionine, L-phenylalanine, $\mathrm{L}$-serine, $\mathrm{L}$-threonine and L-valine are used as sole nitrogen sources, but not acetamide or L-aspartic acid (all at $0.1 \% \mathrm{w} / \mathrm{v})$.

The cell wall peptidoglycan contains $L L$-diaminopimelic acid, the whole organism sugars are glucose and ribose, the major fatty acids are anteiso- $\mathrm{C}_{15: 0}, \mathrm{C}_{16: 0}$, iso- $\mathrm{C}_{16: 0}$ and anteiso- $\mathrm{C}_{17: 0}$, the predominant menaquinones $\mathrm{MK}-9\left(\mathrm{H}_{6}\right)$ 
and MK-9 $\left(\mathrm{H}_{8}\right)$, and the major polar lipids diphosphatidylglycerol, glycophospholipids, phosphatidylethanolamine (diagnostic component), phosphatidylglycerol, phosphatidylmethylethanolamine, phosphatidylinositol, and 3 unknown lipids.

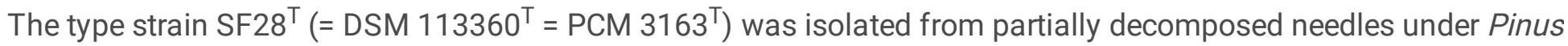
sylvestris trees growing on the southern slope of an inland sand dune in the Toruń Basin, Poland.

Novel streptomycetes isolated from extreme habitats are a rich source of new specialised metabolites, including antibiotics (Rateb et al. 2018; Sivalingam et al. 2019; Sivakala et al. 2021). It is therefore surprising that streptomycetes known to be common in coniferous forest soils (Golińska et al. 2022) have received little attention, especially since they have been shown to be antagonistic to fungal pathogens (Golińska and Dahm 2013; Cao et al. 2020) and can form mutualistic associations with the pine beetle, Dendroctonus frontalis (Strzelczyk and Szpotański 1989; Scott et al. 2008). It is also interesting that $S$. piniterrae jys $28^{\top}$, an isolate from the rhizosphere soil of Pinus yunnanensis, contains a putative gene cluster that encode for the synthesis of heliquinomycins which belong to rubromycin family of compounds (Zhuang et al. 2020). Consequently, the discovery that S. pinistramenti SF $28^{\top}$ shows pronounced activity against diverse fungal plant pathogens provides further evidence that novel Streptomyces species isolated from coniferous forest soils merit greater attention as a source of new bioactive metabolites. It is also interesting that S. pinistramenti SF $28^{\top}$ and S. piniterrae jys $28^{\top}$ are associated with strains that produce novel antibiotics, as exemplified by $S$. decoyicus NRRL ISP- $5087^{\top}$ which produces psicofuranine, a purine nucleoside antibiotic which shows antibacterial and antitumor activity (Eble et al. 1959; Varva et al 1959).

\section{Abbreviations}

A2pm, diaminopimelic acid; ANI, average nucleotide identity; BGCs, biosynthetic gene clusters; BLAST, Basic Local Alignment Search Tool; dDDH, digital DNA-DNA hybridization; DNA, deoxyribonucleic acid; DSMZ, German Collection of Microorganisms and Cell Cultures; GGDC, genome to genome distance calculator; HPLC, highperformance liquid chromatography; IBB, Institute of Biochemistry and Biophysics; ISP, International Streptomyces Project; MIDI, Microbial Identification System; ML, maximum-likelihood; MP, maximum-parsimony; MRE, maximal-relative-error; PCM, Polish Collection of Microorganisms; PUAP, Phylogenetic Analysis Using Parsimony; RAST, Rapid Annotation using Subsystem Technology; rRNA, ribosomal RNA; S., Streptomyces; TLC, thin-layer chromatography; TNT, Tree Analysis New Technology; TYGS, Type Strain Genome Server

\section{Declarations}

\section{Acknowledgements}

We are grateful to Professor Aharon Oren (Hebrew University of Jerusalem) for suggesting the species name.

\section{Author Contributions}

PG and MG conceived the study, PG designed it and MŚ carried out all the experiments and was responsible for the data analyses. MŚ wrote the first draft of the manuscript which was revised by PG and MG. The final version of the manuscript was approved by all of the authors.

\section{Funding}


This work was supported by Grants No. 1207-B and Grants4NCU No. 90-SIDUB.6102.40.2021.G4NCUS1 from

Nicolaus Copernicus University.

\section{Data Availability}

The GenBank accession numbers for the 16S rRNA gene and the whole-genome sequences of strains SF $28^{\top}$ are OK576049 and JAJCXB000000000, respectively.

\section{Conflict of Interest}

The authors declare that they do not have any conflicts of interest.

\section{Ethical statement}

This article does not contain any studies with human participants and/or animals performed by any authors. Formal consent is not required in this study.

\section{References}

1. Abdelkader MSA, Philippon T, Asenjo JA, Bull AT, Goodfellow M, Ebel R, Jaspars M, Rateb ME (2018) Asenjonamides A-C, antibacterial metabolites isolated from Streptomyces asenjonii strain KNN $42 . f$ from an extreme-hyper arid Atacama Desert soil. J Antibiot 71: 425-431. https://doi.org/10.1038/s41429-017-0012-0

2. Abdel-Mageed WM, Lehri B, Jarmusch SA, Miranda K, Al-Wahaibi LH, Stewart HA, Jamieson AJ, Jaspars M, Karlyshev AV (2020) Whole genome sequencing of four bacterial strains from South Shetland Trench revealing biosynthetic and environmental adaptation gene clusters. Mar Genomics 54: 100782. https://doi.org/10.1016/j.margen.2020.100782

3. Álvarez-Álvarez R, Botas A, Albillos SM, Rumbero A, Martín JF, Liras P (2015) Molecular genetics of naringenin biosynthesis, a typical plant secondary metabolite produced by Streptomyces clavuligerus. Microb Cell Fact 14: 178 https://doi.org/10.1186/s12934-015-0373-7

4. Aziz RK, Devoid S, Disz T, Edwards RA, Henry CS, Olsen GJ, Olson R, Overbeek R, Parrello B, Pusch GD, Stevens RL, Vonstein V, Xia F (2012) SEED servers: high-performance access to the SEED genomes, annotations, and metabolic models. PLoS One 7: e48053. https://doi.org/10.1371/journal.pone.0048053

5. Baltz RH (2017) Gifted microbes for genome mining and natural product discovery. J Ind Microbiol Biotechnol 44: 573-588. https://doi.org/10.1007/s10295-016-1815-x

6. Baltz RH (2019) Natural product drug discovery in the genomic era: realities, conjectures, misconceptions, and opportunities. J Ind Microbiol Biotechnol 46: 281-299. https://doi.org/10.1007/s10295-018-2115-4

7. Bankevich A, Nurk S, Antipov D, Gurevich AA, Dvorkin M, Kulikov AS, Lesin VM, Nikolenko SI, Pham S, Prjibelski AD, Pyshkin AV, Sirotkin AV, Vyahhi N, Tesler G, Alekseyev MA, Pevzner PA (2012) SPAdes: a new genome assembly algorithm and its applications to single-cell sequencing. J Comput Biol 19: 455-477. https://doi.org/10.1089/cmb.2012.0021

8. Barka EA, Vatsa P, Sanchez L, Gaveau-Vaillant N, Jacquard C, Meier-Kolthoff JP, Klenk HP, Clément C, Ouhdouch Y, van Wezel GP (2015) Taxonomy, physiology, and natural products of Actinobacteria. Microbiol. Mol Biol Rev 80: 1-43. https://doi.org/10.1128/MMBR.00019-15

9. Barona-Gómez F, Wong U, Giannakopulos AE, Derrick PJ, Challis GL (2004) Identification of a cluster of genes that directs desferrioxamine biosynthesis in Streptomyces coelicolor M145. J Am Chem Soc 126: 16282- 
16283. https://doi.org/10.1021/ja045774k

10. Blin K, Shaw S, Kloosterman AM, Charlop-Powers Z, van Weezel GP, Medema MH, Weber T (2021) antiSMASH 6.0: improving cluster detection and comparison capabilities. Nucleic Acids Res 49(W1): W29-W35. https://doi.org/10.1093/nar/gkab335

11. Bolger AM, Lohse M, Usadel B (2014) Trimmomatic: a flexible trimmer for Illumina sequence data. Bioinformatics 30: 2114-2120. https://doi.org/10.1093/bioinformatics/btu170

12. Boncompagni E, Osteras M, Poggi MC, le Rudulier D (1999) Occurrence of choline and glycine betaine uptake and metabolism in the family Rhizobiaceae and their roles in osmoprotection. Appl Environ Microbiol 65: 2072-2077. https://doi.org/10.1128/AEM.65.5.2072-2077.1999

13. Bull AT (2011) Actinobacteria of the extremobiosphere, In: Horikoshi K (ed) Extremophiles Handbook. Springer Verlag, Tokyo, pp 1204-1240.

14. Bull AT, Stach JE (2007) Marine actinobacteria: new opportunities for natural product search and discovery. Trends Microbiol 15: 491-499. https://doi.org/10.1016/j.tim.2007.10.004

15. Burns J, Holtman DF (1959) Tennecetin: a new antifungal antibiotic: general characteristics. Antibiot Chemother (Northfield) 9: 398-405.

16. Busarakam K, Bull AT, Girard G, Labeda D, van Wezel GP, Goodfellow M (2014) Streptomyces leeuwenhoekii sp. nov., the producer of chaxalactins and chaxamycins, form a distinct branch in Streptomyces gene trees. Antonie van Leeuwenhoek 105: 849-861. https://doi.org/10.1007/s10482-014-0139-y

17. Busarakam K, Bull AT, Trujillo ME, Riescu R, Sangal V, van Wezel GP, Goodfellow M (2016) Modestobacter caceserii sp. nov., novel actinobacteria with an insight into their adaptive mechanisms for survival in extreme hyper-arid Atacama Desert soils. Appl Microbiol 39: 243-251. https://doi.org/10.1016/j.syapm.2016.03.007

18. Busti E, Cavaletti L, Monciardini P, Schumann P, Rohde M, Sosio M, Donadio S (2014) Catenulispora acidiphila gen. nov., sp. nov., a novel, mycelium-forming actinomycete, and proposal of Catenulisporaceae fam. nov. Int J Syst Evol Microbiol 56: 1741-1746. https://doi.org/10.1099/ijs.0.63858-0

19. Cao P, Li C, Wang H, Yu Z Xu X, Wang X, Zhao J, Xiang W (2020) Community structures and antifungal activity of root-associated endophytic actinobacteria in healthy and diseased cucumber plants and Streptomyces sp. HAAG3-15 as a promising biocontrol agent. Microorganisms 8: 236.

https://doi.org/10.3390/microorganisms8020236

20. Carro L, Spröer C, Alonso P, Trujillo ME (2012) Diversity of Micromonospora strains isolated from nitrogen fixing nodules and rhizosphere of Pisum sativum analyzed by multilocus sequence analysis. Syst Appl Microbiol 35: 73-80. https://doi.org/10.1016/j.syapm.2011.11.003

21. Carro L, Nouioui I, Sangal V, Meier-Kolthoff JP, Trujillo ME, Sahin N, Smith DL, Kim KE, Peluso P, Deshpande S, Woyke T, Shapiro N, Kyrpides NC, Klenk HP, Göker M, Goodfelow M (2018) Genome-based classification of micromonosporae with a focus on their biotechnological and ecological potential. Sci Rep 8: 525. https://doi.org/10.1038/s41598-017-17392-0

22. Castro JF, Razmilic V, Gomez-Escribano JP, Andrews B, Asenjo J, Bibb M. (2018) The 'gifted' actinomycete Streptomyces leeuwenhoekii. Antonie van Leeuwenhoek 111: 1433-1448. https://doi.org/10.1007/s10482018-1034-8

23. Chater KF (2016). Recent advances in understanding Streptomyces. F1000 Research 5: 2795. https://doi.org/10.12688/f1000research.9534.1 
24. Chun J, Oren A, Ventosa A, Christensen H, Arahal DR, da Costa MS, Rooney AP, Yi H, Xu X-W, Meyer SD, Trujillo ME (2018) Proposed minimal standards for the use of genome data for the taxonomy of prokaryotes. Int $J$ Syst Microbiol 68: 461-466. https://doi.org/10.1099/ijsem.0.002516

25. De Boer C, Dietz A, Silver WS, Savage GM (1956) Streptolydigin, a new antimicrobial antibiotic. 1. Biologic studies of streptolydigin. Antibiotics Annual 1955-1956: 886-892.

26. Eble TE, Hoeksema H, Boyack GA, Savage GM (1959) Psicofuranine. I. Discovery, isolation, and properties. Antibiot Chemother (Northfield). 9: 419-420.

27. Edgar RC (2004) MUSCLE: multiple sequence alignment with high accuracy and high throughput. Nucleic Acids Res 32:1792-1797. https://doi.org/10.1093/nar/gkh340

28. Etchegaray JP, Inouye M (1999) CspA, CspB and CspG, major cold shock proteins of Escherichia coli, are induced at low temperature under conditions that completely block protein synthesis. J Bacteriol.181: 18271830. https://doi.org/10.1128/JB.181.6.1827-1830.1999

29. Farris JS (1972) Estimating phylogenetic trees from distance matrices. Am Nat 106: 645-668. http://www.jstor.org/stable/2459725

30. Felsenstein J (1985) Confidence limits on phylogenies: an approach using the bootstrap. Evolution 39: 383391. https://doi.org/10.2307/2408678

31. Fiedler HP (2004) Screening for bioactivity. In: Bull AT (ed) Microbial Diversity and Bioprospecting. American Society of Microbiology, Washington DC, pp 324-335.

32. Fujii K, Satomi M, Fukui Y, Matsunobu S, Morifuku Y, Enokida Y (2013) Streptomyces abietis sp. nov., a cellulolytic bacterium isolated from soil of a pine forest. Int J Syst Evol Microbiol 63: 4754-4759. https://doi.org/10.1099/ijs.0.053025-0

33. Funabashi M, Funa N, Horinouchi S (2008) Phenolic lipids synthesized by type III polyketide synthase confer penicillin resistance on Streptomyces griseus. J Biol Chem 283: 13983-13991.

https://doi.org/10.1074/jbc.M710461200

34. Golińska P, Dahm H (2013) Antagonistic properties of Streptomyces isolated from forest soils against fungal pathogens of pine seedlings. Dendrobiology 69: 87-97. http://dx.doi.org/10.12657/denbio.069.010

35. Golińska P, Dahm H, Goodfellow M (2016) Streptacidiphilus toruniensis sp. nov., isolated from a pine forest soil. Antonie van Leeuwenhoek 109: 1583-1591. https://doi.org/10.1007/s10482-016-0759-5

36. Golińska P, Goodfellow M, Sangal V (2022) Entering poorly charted waters: the biology of the filamentous acidloving Actinomycetia and Acidimicrobia. In: Kurtboke I (ed.) Actinomycetes in Extreme and Marine Environments: an Unexhausted Source for Microbial Biotechnology. CRC Press, Boca Raton, Florida USA.

37. Golińska P, Kim B-Y, Dahm H, Goodfellow M (2013a) Streptacidiphilus hamsterleyensis sp. nov., isolated from a spruce forest soil. Antonie van Leeuwenhoek 104: 965-972. https://doi.org/10.1007/s10482-013-0015-1

38. Golińska P, Wang D, Goodfellow M (2013b) Nocardia aciditolerans sp. nov., isolated from a spruce forest soil. Antonie van Leeuwenhoek 103: 1079-1088. https://doi.org/10.1007/s10482-013-9887-3

39. Golińska P, Świecimska M, Montero-Calasanz MDC, Yaramis A, Igual JM, Bull AT, Goodfellow M (2020) Modestobacter altitudinis sp. nov., a novel actinobacterium isolated from Atacama Desert soil. Int J Syst Evol Microbiol 70: 3513-3527. https://doi.org/10.1099/ijsem.0.004212

40. Goloboff PA, Farris JS, Nixon KC (2008) TNT, a free program for phylogenetic analysis. Cladistics 24: $774-786$. https://doi.org/10.1111/j.1096-0031.2008.00217.x 
41. Gomez-Escribano JP, Castro JF, Razmilic V, Chandra G, Andrews B, Asenjo JA, Bibb MJ (2015) The Streptomyces leeuwenhoekii genome: de novo sequencing and assembly in single contigs of the chromosome, circular plasmid pSLE1 and linear plasmid pSLE2. BMC Genomics 16: 485. https://doi.org/10.1186/s12864015-1652-8

42. Goodfellow M, Williams ST (1983) Ecology of actinomycetes. Ann Rev Microbiol 37: 189-216.

43. Goodfellow M, Hill IR, Gray TRG (1967) Bacteria in a pine forest soil. In: Gray TRG, Parkinson D (ed) The Ecology of Soil Bacteria, University Press, Liverpool, pp 500-515.

44. Goodfellow M, Busarakam K, Idris H, Labeda DP, Nouioui I, Brown R, Kim BY, Del Carmen Montero-Calasanz M, Andrews BA, Bull AT (2017) Streptomyces asenjonii sp. nov., isolated from hyper-arid Atacama Desert soils and emended description of Streptomyces viridosporus Pridham et al. 1958. Antonie van Leeuwenhoek. 110: 11331148. https://doi.org/10.1007/s10482-017-0886-7

45. Goodfellow M, Nouioui I, Sanderson R, Xie F, Bull AT (2018) Rare taxa and dark microbial matter: novel bioactive actinobacteria abound in Atacama Desert soils. Antonie van Leeuwenhoek 111: 1315-1332. https://doi.org/10.1007/s10482-018-1088-7

46. Guan N, Liu L (2020) Microbial response to acid stress: mechanisms and applications. Appl Microbiol Biotechnol 104: 51-65. https://doi.org/10.1007/s00253-019-10226-1

47. Hamm PS, Caimi NA, Northup DE, Valdez EW, Buecher DC, Dunlap CA, Labeda DP, Lueschow S, Porras-Alfaro A (2017) Western bats as a reservoir of novel Streptomyces species with antifungal activity. Appl Environ Microbiol 83: e03057-16. https://doi.org/10.1128/AEM.03057-16

48. Harris JL (1986) Modified method for fungal slide culture. J Clin Microbiol 9: 460-461. https://doi.org/10.1128/jcm.24.3.460-461.1986

49. Hasegawa T, Takizawa M, Tanida S (1983) A rapid analysis for chemical grouping of aerobic actinomycetes. J Gen Appl Microbiol 29: 319-322. https://doi.org/10.2323/jgam.29.319

50. Hickson ID (2003) Rec Q helicases: caretakers of the genome. Nat Rev Cancer 3: 169-178. https://doi.org/10.1038/nrc1012

51. Jin L, Zhao Y, Song W, Duan L, Jiang S, Wang X, Zhao J, Xiang W (2019) Streptomyces inhibens sp. nov., a novel actinomycete isolated from rhizosphere soil of wheat (Triticum aestivum L.). Int J Syst Evol Microbiol 69: 688-695. https://doi.org/10.1099/ijsem.0.003204

52. Jones KI (1949) Fresh isolates of actinomycetes in which the presence of sporogenous aerial mycelia is a fluctuating characteristic. J Bacteriol 57: 141-145. https://doi.org/10.1128/jb.57.2.141-145.1949

53. Kaewkla O, Suriyachadkun C, Franco CMM (2021) Streptomyces adelaidensis sp. nov., an actinobacterium isolated from the root of Callitris preissii with potential for plant growth-promoting properties. Arch Microbiol 203: 3341-3352. https://doi.org/10.1007/s00203-021-02308-4

54. Kang J, Blaser MJ (2006) UvRD helicase suppresses recombination and DNA-damage induced deletions. J Bacteriol 188: 5050-5059. https://doi.org/10.1128/JB.00275-06

55. Kämpfer P (2012) Genus Streptomyces. In: Goodfellow M, Kämpfer P, Busse HJ, Trujillo ME, Suzuki KI, Ludwig W, Whitman WB (ed) Bergey's Manual of Systematic Bacteriology, $2^{\text {nd }}$ edn., vol 5, The Actinobacteria, Part B. Springer, New York, pp 1455-1767.

56. Kawato M, Shinobu R (1959) On Streptomyces herbaricolor sp. nov., supplement: a simple technique for microscopical observation. Mem Osaka Univ Lib Arts Educ B Nat Sci 8: 114-119. 
57. Kelly KL (1958) Centroid notations for the revised ISCC-NBS color name blocks. J Res Nat Bur Standards USA 61:427. https://dx.doi.org/10.6028/jres.061.035

58. Kim SB, Falconer C, Williams E, Goodfellow M (1998) Streptomyces thermocarboxydovorans sp. nov. and Streptomyces thermocarboxydus sp. nov., two moderately thermophilic carboxydotrophic species from soil. Int J Syst Bacteriol 48: 59-68. https://doi.org/10.1099/00207713-48-1-59

59. Kim YJ, Moon MH, Song JY, Smith CP, Hong S-K and Chang YK (2008) Acidic pH shock induces the expressions of a wide range of stress-response genes. BMC Genomics 9, 604. https://doi.org/10.1186/14712164-9-604

60. Kimura M (1980) A simple method for estimating evolutionary rate of base substitutions through comparative studies of nucleotide sequences. J Mol Evol 16:111-120. https://doi.org/10.1007/BF01731581

61. Komaki H, Tamura T (2019) Reclassification of Streptomyces rimosus subsp. paromomycinus as Streptomyces paromomycinus sp. nov. Int J Syst Evol Microbiol 69:2577-2583.

https://doi.org/10.1099/ijsem.0.003545

62. Králová S, Sandoval-Powers M, Fawwal DV, Degnes KF, Lewin AS, Klinkenberg G, Nguyen GS, Liles MR, Wentzel A (2021) Streptomyces tardus sp. nov.: A slow-growing actinobacterium producing candicidin, isolated from sediments of the Trondheim Fjord. Front. Microbiol. 12:714233. https://doi.org/10.3389/fmicb.2021.714233

63. Kroppenstedt RM (1985) Fatty acids and menaquinones of actinomycetes and related organisms. In: Goodfellow M, Minnikin DE (ed) Chemical Methods in Bacterial Systematics, Academic Press, London pp 173200.

64. Kumar S, Stecher G, Tamura K (2016) MEGA7: Molecular Evolutionary Genetics Analysis version 7.0 for bigger datasets. Mol Biol Evol 33:1870-1874. https://doi.org/10.1093/molbev/msw054

65. Kumar Y, Goodfellow M (2010) Reclassification of Streptomyces hygroscopicus strains as Streptomyces aldersoniae sp. nov., Streptomyces angustmyceticus sp. nov., comb. nov., Streptomyces ascomycinicus sp. nov., Streptomyces decoyicus sp. nov., comb. nov., Streptomyces milbemycinicus sp. nov. and Streptomyces wellingtoniae sp. nov. Int J Syst Evol Microbiol 60(Pt 4):769-775. https://doi.org/10.1099/ijs.0.012161-0

66. Küster E, Williams ST (1964) Selection of media for isolation of streptomycetes. Nature 202:928-929. https://doi.org/10.1038/202928a0

67. Kusuma AB, Nouioui I, Goodfellow M (2021) Genome-based classification of the Streptomyces violaceusniger clade and description of Streptomyces sabulosicollis sp. nov. from an Indonesian sand dune. Antonie van Leeuwenhoek 114(6):859-873. https://doi.org/10.1007/s10482-021-01564-0

68. Kuykendall LD, Roy MA, O’Neill JJ, Devine TE (1988) Fatty acids, antibiotic resistance, and deoxyribonucleic acid homology groups of Bradyrhizobium japonicum. Int J Syst Bacteriol 38:358-361.

https://doi.org/10.1099/00207713-38-4-358

69. Labeda DP, Dunlap CA, Rong X, Huang Y, Doroghazi JR, Ju KS, Metcalf WW (2017) Phylogenetic relationships in the family Streptomycetaceae using multi-locus sequence analysis. Antonie van Leeuwenhoek 110:563-583. https://doi.org/10.1007/s10482-016-0824-0

70. Labeda DP, Goodfellow M, Brown R, Ward AC, Lanoot B, Vancanneyt M, Swings J, Kim S-B, Liu Z, Chun J, Tamura T, Oguchi A, Kikuchi T, Kikuchi H, Nishii T, Tsuji K, Yamaguchi Y, Tase A, Takahashi M, Sakane T, Suzuki KI, Hatano K (2012) Phylogenetic study of the species within the family Streptomycetaceae. Antonie van Leeuwenhoek 101:73-104. https://doi.org/10.1007/s10482-011-9656-0 
71. le Roes-Hill M, Prins A, Meyers PR (2018) Streptomyces swartbergensis sp. nov., a novel tyrosinase and antibiotic producing actinobacterium. Antonie van Leeuwenhoek 111:589-600.

https://doi.org/10.1007/s10482-017-0979-3

72. Lee I, Ouk Kim Y, Park SC, Chun J. (2016) OrthoANI: an improved algorithm and software for calculating average nucleotide identity. Int J Syst Evol Microbiol 66(2):1100-1103.

https://doi.org/10.1099/ijsem.0.000760

73. Lefort V, Desper R, Gascuel O (2015) FastME 2.0: a comprehensive, accurate, and fast distance-based phylogeny inference program. Mol Biol Evol 32:2798-2800. https://doi.org/10.1093/molbev/msv150

74. Li JS, Bi YT, Dong C, Yang JF, Liang WD (2011) Transcriptome analysis of adaptive heat shock response of Streptococcus thermophilus. PLoS One 6, e25777. https://doi.org/10.1371/journal.pone.0025777

75. Liu C, Ye L, Li Y, Jiang S, Liu H, Yan K, Xiang W, Wang X (2016) Streptomyces kronopolitis sp. nov., an actinomycete that produces phoslactomycins isolated from a millipede (Kronopolites svenhedind Verhoeff). Int J Syst Evol Microbiol 66(12):5352-5357. https://doi.org/10.1099/ijsem.0.001520

76. Lorite MJ, Tachil J, Sanjuan J, Meyer O, Bedmar EJ (2000) Carbon monoxide dehydrogenase activity in Bradyrhizobium japonicum. Appl Environ Microbiol 66, 1871-1876. https://doi.org/10.1128/AEM.66.5.18711876.2000

77. Madhaiyan M, Poonguzhali S, Saravanan VS, Duraipandiyan V, Al-Dhabi NA, Pragatheswari D, Santhanakrishnan P, Kim SJ, Weon HY, Kwon SW (2016) Streptomyces pini sp. nov., an actinomycete isolated from phylloplane of pine (Pinus sylvestris L.) needle-like leaves. Int J Syst Evol Microbiol 66:4204-4210. https://doi.org/10.1099/ijsem.0.001336

78. Madhaiyan M, Saravanan VS, See-Too W-S (2020) Genome-based analyses reveal the presence of 12 heterotypic synonyms in the genus Streptomyces and emended descriptions of Streptomyces bottropensis, Streptomyces celluloflavus, Streptomyces fulvissimus, Streptomyces glaucescens, Streptomyces murinus, and Streptomyces variegatus. Int J Syst Evol Microbiol 70:6 https://doi.org/10.1099/ijsem.0.004217

79. Meier-Kolthoff JP, Göker M (2019) TYGS is an automated high-through put platform for state-of- the-art genome-based taxonomy. Nat Commun 10:2182. https://doi.org/10.1038/s41467-019-10210-3

80. Meier-Kolthoff JP, Auch AF, Klenk H-P, Göker M (2013a) Genome sequence based species delimitations with constant intervals and improved distance functions. BMC Bioinform 14:60. https://doi.org/10.1186/14712105-14-60

81. Meier-Kolthoff JP, Göker M, Spröer C, Klenk H-P (2013b) When should a DDH experiment be mandatory in microbial taxonomy? Arch Microbiol 195:413-418. https://doi.org/10.1007/s00203-013-0888-4

82. Miller LT (1982) Single derivatization method for bacterial fatty acid methyl esters including hydroxy acids. J Clin Microbiol 16:584-586. https://doi.org/10.1128/jcm.16.3.584-586.1982

83. Minnikin DE, O'Donnell AG, Goodfellow M, Alderson G, Athalye M, Schaal A, Parlett JH (1984) An integrated procedure for extracting bacterial isoprenoid quinones and polar lipids. J Microbiol Methods 2:233-241. https://doi.org/10.1016/0167-7012(84)90018-6

84. Murray PR, Boron EJ, Pfaller MA, Tenover FC, Yolken RH (1999) Manual of Clinical Microbiology, $7^{\text {th }}$ edn., ASM Press, Washington, DC.

85. Nakano C, Funa N, Ohnishi Y, Horinouchi S (2012) The O-methyltransferase Srsb catalyzes the decarboxylative methylation of alkylresorcylic acid during phenolic lipid biosynthesis by Streptomyces griseus. J Bacteriol 194:1544-1551. https://doi.org/10.1128/JB.06406-11

Page $21 / 27$ 
86. Nau-Wagner G, Opper D, Rolbetzk A, Boch J, Kempf B, Hoffmann T, Bremer E (2012) Genetic control of osmoadaptive glycine betaine synthesis in Bacillus subtilis through the choline-sensing and glycine-betaineresponsive GbsR repressor. J Bacteriol 194, 2703-2714. https://doi.org/10.1128/JB.06642-11

87. Nishimura H, Kimura T (1953) On a yellow crystalline antibiotic, identical with aureothricin isolated from a new species of Streptomyces, 39a, and its taxonomic study. J Antibiot (Tokyo), 6(2):57-65.

88. Normand P, Gury J, Pujic P, Chouaia B, Crotti E, Brusetti L, Daffonchio D, Vacherie B, Barbe V, Médigue C, Calteau A, Ghodhbane-Gtari F, Essoussi I, Nouioui I, Abbassi-Ghozzi I, Gtari M (2012) Genome sequence of radiation-resistant Modestobacter marinus strain BC501, a representative actinobacterium that thrives on calcareous stone surfaces. J Bacteriol 194, 4773-4774. https://doi.org/10.1128/JB.01029-12

89. Nouioui I, Carro L, Garcia-Lopez M, Meier-Kolthoff JP, Woyke T, Kyrpides NC, Pukall R, Klenk H-P, Goodfellow M, Göker M (2018) Genome-based taxonomic classification of the phylum Actinobacteria. Front Microbiol 9:2007. https://doi.org/10.3389/fmicb.2018.02007

90. O’Donnell AG, Falconer C, Goodfellow M, Ward AC, Williams E (1993) Biosystematics and diversity amongst novel carboxydotrophic actinomycetes. Antonie van Leeuwenhoek 64:325-340.

https://doi.org/10.1007/BF00873091

91. Omura S, Ikeda H, Ishikawa J, Hanamoto A, Takahashi C, Shinose M, Takahashi Y, Horikawa H, Nakazawa H, Osonoe T, Kikuchi H, Shiba T, Sakaki Y, Hattori M (2001) Genome sequence of an industrial microorganism Streptomyces avermitilis: deducing the ability of producing secondary metabolites. Proc Natl Acad Sci U S A 9:98(21):12215-20. https://doi.org/10.1073/pnas.211433198

92. Ondov BD, Treangen TJ, Melsted P, Mallonee AB, Bergman NH, Koren S, Phillippy AM (2016) Mash: fast genome and metagenome distance estimation using MinHash. Genome Biol 17:1-14. https://doi.org/10.1186/s13059-016-0997-x_

93. Pattengale ND, Alipour M, Bininda-Emonds OR, Moret BM, Stamatakis A (2010) How many bootstrap replicates are necessary? J Comput Biol 17:337-354. https://doi.org/10.1007/978-3-642-02008-7_13

94. Peng C, Zhuang X, Gao C, Wang Z, Zhao J, Huang S-X, Liu C, Xiang W (2021) Streptomyces typhae sp. nov., a novel endophytic actinomycete with antifungal activity isolated the root of cattail (Typha angustifolia L.). Antonie van Leeuwenhoek 114(6):823-833. https://doi.org/10.1007/s10482-021-01561-3

95. Prabhu J, Schauwecker F, Grammel N, Keller U, Bernhard M (2004) Functional expression of the ectoine hydroxylase gene (thpD) from Streptomyces chrysomallus in Halomonas elongate. Appl Environ Microbiol 70(5):3130-3132. https://doi.org/10.1128/AEM.70.5.3130-3132.2004

96. Qi D, Zou L, Zhou D, Chen Y, Gao Z, Feng R, Zhang M, Li K, Xie J, Wang W (2019) Taxonomy and broadspectrum antifungal activity of Streptomyces sp. SCA3-4 isolated from rhizosphere soil of Opuntia stricta. Front Microbiol 10:1390. https://doi.org/10.3389/fmicb.2019.01390

97. Qi Y, Nepal KK, Blodgett JAV (2021) A comparative metabologenomic approach reveals mechanistic insights into Streptomyces antibiotic crypticity. PNAS 118(31):e2103515118. https://doi.org/10.1073/pnas.2103515118

98. Rateb ME, Ebel R, Jaspars M (2018) Natural product diversity of actinobacteria in the Atacama Desert. Antonie van Leeuwenhoek 111:1467-1477. https://doi.org/10.1007/s10482-018-1030-z

99. Richter M, Rosselló-Móra R (2009) Shifting the genomic gold standard for the prokaryotic species definition. PNAS 106(45):19126-19131. https://doi.org/10.1073/pnas.0906412106 
100. Rodriguez-R LM, Konstantinidis KT (2016) The enveomics collection: a tool box for specialized analyses of microbial genomes and metagenomes. Peer J Preprints 4:e1900v1.

https://doi.org/10.7287/peerj.preprints.1900v1

101. Rong X, Huang Y (2012) Taxonomic evaluation of the Streptomyces hygroscopicus clade using multilocus sequence analysis and DNA-DNA hybridization, validating the MLSA scheme for systematics of the whole genus. Syst Appl Microbiol, 35:7-18. https://doi.org/10.1016/j.syapm.2011.10.004

102. Rong X Huang Y (2014) Multi-locus sequence analysis: taking prokaryotic systematics to the next level. In: Goodfellow M, Sutcliffe I, Chun J. (eds). Methods in Microbiology, Academic Press, 41, pp 221-251.

103. Saitou N, Nei M (1987) The neighbour-joining method: A new method for constructing phylogenetic trees. Mol Biol Evol 4:406-425. https://doi.org/10.1093/oxfordjournals.molbev.a040454

104. Sasser MJ (1990) Identification of bacteria by gas chromatography of cellular fatty acids, Del: Microbial ID Inc, Newark.

105. Scott JJ, Oh D-C, Yuceer MC, Klepzig KD, Clardy J, Currie CR (2008) Bacterial protection of beetle-fungus mutualism. Science 322:63. https://doi.org/10.1126/science.1160423

106. Seemann T (2014) Prokka: rapid prokaryotic genome annotation. Bioinformatics 30, 20682069. https://doi.org/10.1093/bioinformatics/btu153

107. Sharma D, Mayilraj S, Manhas RK (2014) Streptomyces amritsarensis sp. nov., exhibiting broad-spectrum antimicrobial activity. Antonie van Leeuwenhoek 105, 943-949. https://doi.org/10.1007/s10482-014-0151-2

108. Shirling EB, Gottlieb D (1966) Methods for characterization of Streptomyces species. Int J Syst Bacteriol 16:313-340. https://doi.org/10.1099/00207713-16-3-313

109. Singh R, Dubey AK (2018) Diversity and applications of endophytic actinobacteria of plants in special and other ecological niches. Front Microbiol 8:9:1767. https://doi.org/10.3389/fmicb.2018.01767

110. Sivakala KK, Gutiérrez-García K, Jose PA, Thinesh T, Anandham R, Barona-Gómez F, Sivakumar N (2021) Desert environments facilitate unique evolution of biosynthetic potential in Streptomyces. Molecules 26:588. https://doi.org/10.3390/molecules26030588

111. Sivalingam P, Hong K, Pote K, Prabakar K (2019) Extreme environment Streptomyces: potential sources for new antibacterial and anticancer drug leads? Int J Microbiol 2019:5283948.

https://doi.org/10.1155/2019/5283948

112. Spohn M, Edenhart S, Alanjary M, Ziemert N, Wibberg D, Kalinowski J, Niedermeyer THJ, Stegmann E, Wohlleben W (2018) Identification of a novel aminopolycarboxylic acid siderophore gene cluster encoding the biosynthesis of ethylenediaminesuccinic acid hydroxyarginine (EDHA). Metallomics 10(5):722-734. https://doi.org/10.1039/c8mt00009c

113. Stamatakis A (2014) RAxML version 8: a tool for phylogenetic analysis and post-analysis of large phylogenies. Bioinformatics 30:1312-1313. https://doi.org/10.1093/bioinformatics/btu033

114. Staneck JL, Roberts GD (1974) Simplified approach to the identification of aerobic actinomycetes by thin layer chromatography. Appl Microbiol 28:226-231. https://doi.org/10.1128/am.28.2.226-231.1974

115. Strzelczyk E, Szpotański T (1989) Cellulolytic and pectolytic activity of streptomycetes isolated from root-free soil, rhizosphere and mycorrhizosphere of pine (Pinus sylvestris L.). Biol Fertil Soils 7:4:365-369. https://doi.org/10.1007/bf00257834

116. Świecimska M, Golińska P, Wypij M, Goodfellow M (2021) Genomic-based classification of Catenulispora pinisilvae sp. nov., novel actinobacteria isolated from a pine forest soil in Poland and emended description of 
Catenulispora rubra. Syst Appl Microbiol 44:1. https://doi.org/10.1016/j.syapm.2020.126164

117. Swofford D (2002) PAUP*: Phylogenetic Analysis Using Parsimony (* and other methods). ver. 4, Sinauer Associates, Sunderland, MA.

118. Tao M, Wang L, Wendt-Pienkowski E, George NP, Galm U, Zhang G, Coughlin JM, Shen B (2007) The tallysomycin biosynthetic gene cluster from Streptoalloteichus hindustanus E465-94 ATCC 31158 unveiling new insights into the biosynthesis of the bleomycin family of antitumor antibiotics. Mol Biosyst 3(1):60-74. https://doi.org/10.1039/b615284h

119. Tietz JT, Schwalen CJ, Patel PS, Maxson T, Blair PM, Tai H-C, Zakai UI, Mitchell DA (2017) A new genomemining tool redefines the lasso peptide biosynthetic landscape. Nat Chem Biol 13(5):470-478. https://doi.org/10.1038/nchembio.2319

120. van der Aart LT, Nouioui I, Kloosterman A, Igual J-M, Willemse J, Goodfellow M, van Wezel GP (2019) Polyphasic classification of the gifted natural product producer Streptomyces roseifaciens sp. nov. Int J Syst Evol Microbiol 69:4. https://doi.org/10.1099/ijsem.0.003215

121. Vavra JJ, Dietz A, Churchill BW, Siminoff P, Koepsell HJ (1959) Psicofuranine. III. Production and biological studies. Antibiot Chemother (Northfield). 9(7): 427-31.

122. Waksman SA, Henrici AT (1943) The nomenclature and classification of the actinomycetes. J Bacteriol 46:337-341. https://doi.org/10.1128/jb.46.4.337-341.1943

123. Wayne LG, Brenner DJ, Colwell RR, Grimont PAD, Kandler O, Krichevsky MI, Moore LH, Moore WEC, Murray RGE, Stackebrandt E, Starr MP, Trüper HG (1987) International Committee on Systematic Bacteriology. Report on the ad hoc committee on reconciliation of approaches to bacterial systematics. Int J Syst Bacteriol 37:463-465. https://doi.org/10.1099/00207713-37-4-463

124. Williams ST, Davies FL, Mayfield Cl, Khan MR (1971) Studies on the ecology of actinomycetes in soil. II. The pH requirements of streptomycetes in acid soils. Soil Biol Biochem 3: 187-195.

125. Williams ST, Goodfellow M, Alderson G (1983) Genus Streptomyces Waksman and Henrici 1943, 339AL. In: Williams ST, Sharpe ME, Holt JG (ed) Bergey's Manual of Systematic Bacteriology, Vol. 4, Williams and Wilkins, Baltimore, pp 2452-2492.

126. Williams ST, Goodfellow M, Alderson G, Wellington EMH, Sneath PHA, Sackin MJ (1983) Numerical classification of Streptomyces and related genera. J Gen Microbiol 129:1743-1813.

https://doi.org/10.1099/00221287-129-6-1743

127. Wu C, van der Heul HU, Melnik AV, et al. (2019) Lugdunomycin, an angucycline-derived molecule with unprecedented chemical architecture. Angew Chem Int Ed Engl 58(9):2809-2814.

https://doi.org/10.1002/anie.201814581

128. Yoon S-H, Ha S-M, Kwon S, Lim J, Kim Y, Seo H, Chung J (2017) Introducing EzBioCloud: a taxonomically united database of 16S rRNA and whole genome assemblies. Int J Syst Evol Microbiol 67:1613-1617. https://doi.org/10.1099/ijsem.0.001755

129. Yu F, Zaleta-Rivera K, Zhu X, Huffman J, Millet JC, Harris SD, Yuen G, Li XC, Du L (2007) Structure and biosynthesis of heat-stable antifungal factor (HSAF), a broad-spectrum antimycotic with a novel mode of action antimicrob agents. Chemother 51(1):64-72. https://doi.org/10.1128/AAC.00931-06

130. Zhao S, Ye L, Liu C, Abagana AY, Zheng W, Sun P, Li J, Xiang W, Wang X (2017) Streptomyces gamaensis sp. nov., a novel actinomycete with antifungal activity isolated from soil in Gama, Chad. Antonie van Leeuwenhoek 110:471-477. https://doi.org/10.1007/s10482-016-0816-0

Page 24/27 
131. Zhuang X, Wang Z, Peng C, Su C, Gao C, Wang Y, Huang S, Liu C (2020) Characterization of Streptomyces piniterrae sp. nov. and identification of the putative gene cluster encoding the biosynthesis of heliquinomycins. Microorganisms 8(4):495. https://doi.org/10.3390/microorganisms8040495

132. Zhuang X, Wang Z, Peng C, Su C, Gao C, Wang Y, Huang S, Liu C (2020) Characterization of Streptomyces piniterraesp. nov. and identification of the putative gene cluster encoding the biosynthesis of heliquinomycins. Microorganisms 31;8(4):495. https://doi.org/10.3390/microorganisms8040495

133. Redenbach M, Kieser HM, Denapaite D, Eichner A, Cullum J, Kinashi H, Hopwood DA (1996) A set of ordered cosmids and a detailed genetic and physical map for the $8 \mathrm{Mb}$ Streptomyces coelicolor A3(2) chromosome. Mol Microbiol. 21(1):77-96. https://doi.org/10.1046/j.1365-2958.1996.6191336.x

\section{Figures}

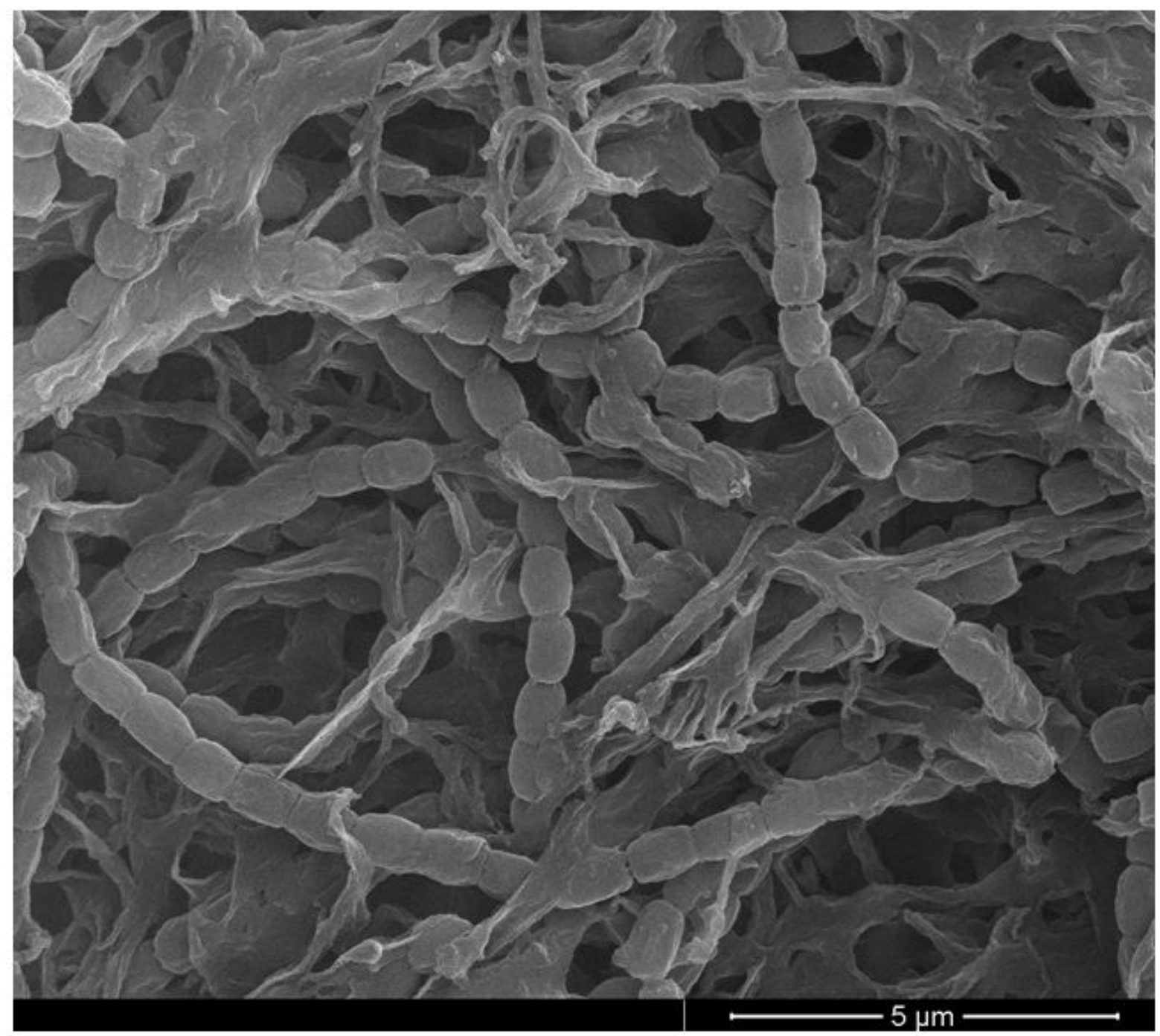

\section{Figure 1}

Scanning electron micrograph of isolate $\mathrm{SF} 28^{\top}$ showing straight chains of cylindrical spores with smooth surfaces following growth on ISP 2 agar for 4 weeks at $28^{\circ} \mathrm{C}$. Bar, $5 \mu \mathrm{m}$ 


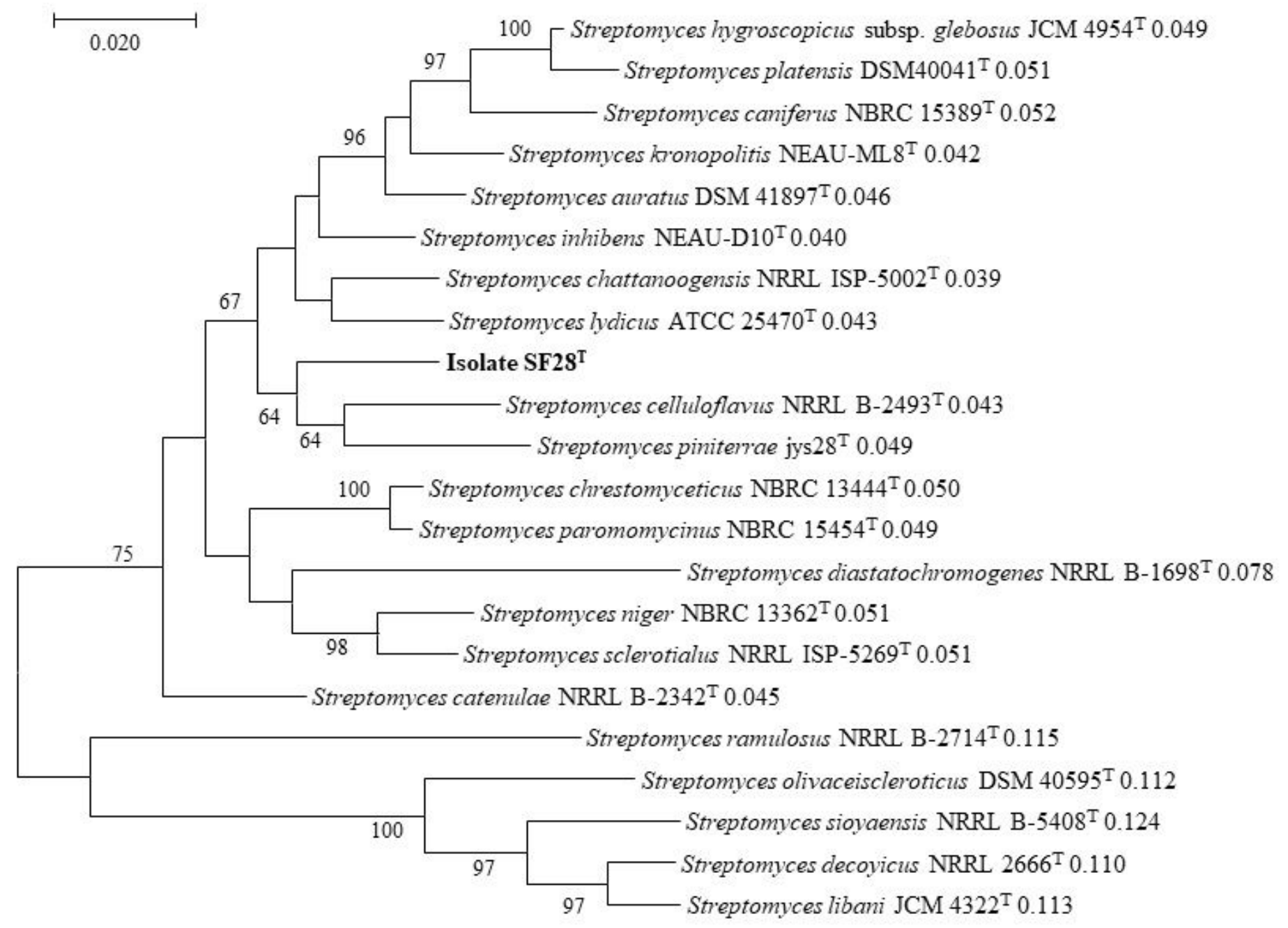

Figure 2

Maximum-likelihood tree based on MLSA analysis of concatenated sequences from the 16S rRNA gene and five housekeeping genes ( $\operatorname{atp} D, g y r B, \operatorname{rec} A, r p o B$ and $\operatorname{trp} B$ ) showing relationships between isolate $S F 28^{\top}$ and the type strains of related Streptomyces species. The numbers at the nodes are bootstrap support values over $60 \%$. Bar, 0.020 substitutions per nucleotide position. 


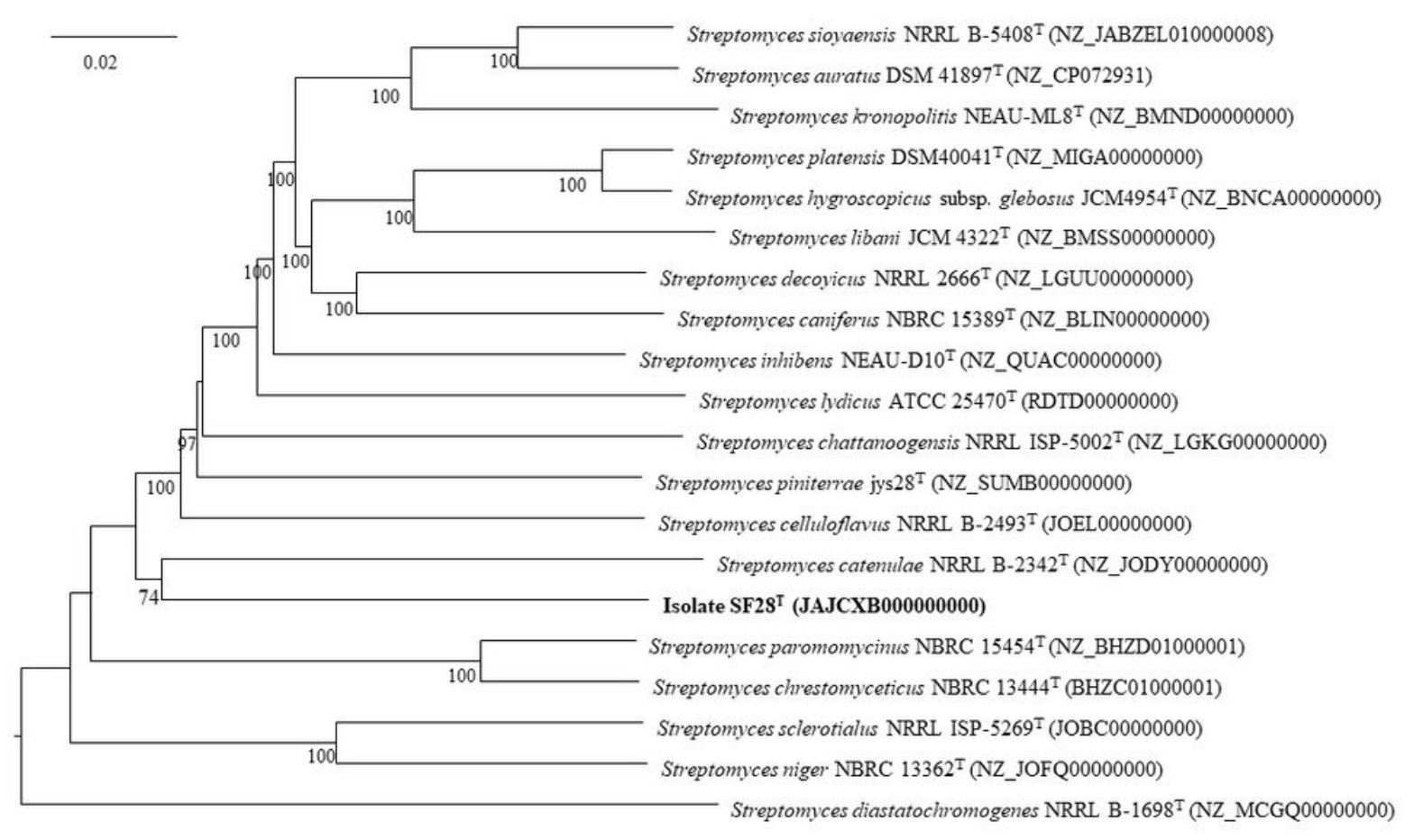

\section{Figure 3}

Phylogenomic tree showing relationships between isolate $S F 28^{\top}$ and the type strains of the most closely related Streptomyces species constructed using the TYGS server. The numbers above the branches are GBDP pseudobootstrap support values greater than $60 \%$ from 100 replications with an average branch support of $95.4 \%$ The tree was rooted at the midpoint (Farris, 1962)

\section{Supplementary Files}

This is a list of supplementary files associated with this preprint. Click to download.

- SupplementaryFigures30.12.2021.pptx

- Tables1.pdf

- Tables2.pdf

- Tables3.pdf

- Tables4.pdf

- Tables5.pdf

- Tables6.pdf

- Tables7.pdf 